\title{
NEOLITICKÝ HROB (?) A KULTOVÝ OBJEKT ZO STARŠEJ DOBY BRONZOVEJ V NITRE-DOLNÝCH KRŠKANOCH ${ }^{1}$
}

\author{
M A T E J R U T T K A Y
}

\begin{abstract}
A Neolithic Grave (?) and a Feature with Cult Function from the Early Bronze Age in Nitra-Dolné Krškany. In 2003, a feature - presumably a grave - was uncovered during an investigation in the southern part of Nitra-Dolné Krškany. Based on the radiocarbon dating, the grave was dated to the end of the Late Neolithic (5830 $\pm 40 \mathrm{BP})-$ most likely the phase I of Lengyel culture. Due to the violation of the contexts, it was impossible to determine whether the feature was a grave within a settlement or a burial at the bottom of a storage pit. We were also able to obtain new knowledge about the feature no. 16 - a conical storage pit with five skeletons lying on its bottom. The radiocarbon dating indicates that the feature could be dated between $3570 \pm 35$ and $3550 \pm 35$ BP. Feature no. 16 can be linked with Nitra culture, probably its Nitra-Únětice phase. The context indicates that the bodies were intentionally deposited in the feature (not discarded). The central skeleton is, most likely, a man in a so-called frog position with arms in an artificial adoration gesture. Above him was laid a child who apparently died violently. The find allows various interpretations. However, the author prefers the explanation that the deceased were intentionally deposited in the grave with a certain cult intention.
\end{abstract}

Keywords: Western Slovakia, Neolithic, Early Bronze Age, Lengyel culture, grave (?), storage pit with skelettons.

\section{ÚVOD}

Archeologický výskum v okolí Nitry prináša neustále nové nálezy. O výskum a publikovanie mnohých významných pamiatok z praveku a najmä doby bronzovej sa zaslúžil práve jubilant prof. PhDr. Jozef Bátora, DrSc., ktorému s úctou venujem tento príspevok. Jeho cielom je základná informácia o náleze hrobu zo záveru mladšej doby kamennej a jamy s piatimi ludskými jedincami zo staršej doby bronzovej doplnená novým rádiouhlíkovým datovaním.

V lete roku 2003 sa uskutočnil záchranný archeologický výskum na stavbe predajne a skladu firmy Tonex v Nitre, v mestskej časti Dolné Krškany (Ruttkay 2004). Nálezisko leží na pravobrežnej, od západu $\mathrm{k}$ východu klesajúcej terase rieky Nitra, na južnom okraji katastra obce, oproti areálu firmy Plastika Nitra, v nadmorskej výške 136,2-137,6 m n. m., približne 50-150 m od okraja terasy (obr. 1).

Výskum sa koncentroval iba na miesta, ktorým hrozilo bezprostredné narušenie stavebnou činnostou (základové ryhy, siete a výkopy pre pätky). Po dohode s investorom bola možná realizácia d’alších zistovacích rezov. Práve vd’aka nim sa podarilo zachytil aj objekt č. 16 . V ostatných priestoroch stavebný projekt predpokladal navýšenie terajšieho terénu o približne $1 \mathrm{~m}$, čo sa aj udialo. Celkove sa preskúmalo 18 objektov z mladšej doby kamennej, doby bronzovej a halštatskej a zo stredoveku, ako aj 3 hroby so štyrmi jedincami - jeden neolitický a tri, z toho jeden dvojhrob, zo stredoveku. Priebeh výskumu skomplikovali nepriaznivé klimatické pomery (extrémne sucho) a obmedzené časové možnosti na jeho realizáciu.

Už povrchový prieskum a následne aj samotný výskum preukázal vel'kú koncentráciu neolitických nálezov. Na viacerých miestach sa zachytila hnedočierna kultúrna vrstva, ktorá obsahovala nálezy z mladšej doby kamennej. Vrstva bola na mnohých úsekoch narušená, respektíve zničená či už zemnými prácami, alebo dávnejšou polnohospodárskou činnostou. Medzi nálezmi prevládali zlomky keramiky, štiepané kamenné nástroje a odštepy a dve kamenné brúsené sekery. Odkryli sa tiež dve sídliskové jamy a fragment žlabu. Jednoznačný doklad neolitických obydlí sa nezachytil.

\section{HROB Č. 1 - ARCHEOLOGICKÝ KONTEXT, OPIS NÁLEZOV A VYHODNOTENIE}

Hrob č. 1 so ženou vo veku maturus II/50-60 rokov (antropologické určenie podla Jakab 2005) sa zistil pri začistovaní plochy (obr. 2). Hrob bol narušený odhumusovaním priestoru pred príchodom archeológa.

Hrobová (?) jama:

Ludské kosti sa zistili na rozhraní ornice a hnedočiernej kultúrnej vrstvy. V dôsledku výrazného narušenia hornej časti sa tvar jamy nepodarilo jednoznačne dokumentovat' a ani rekonštruovat'. 


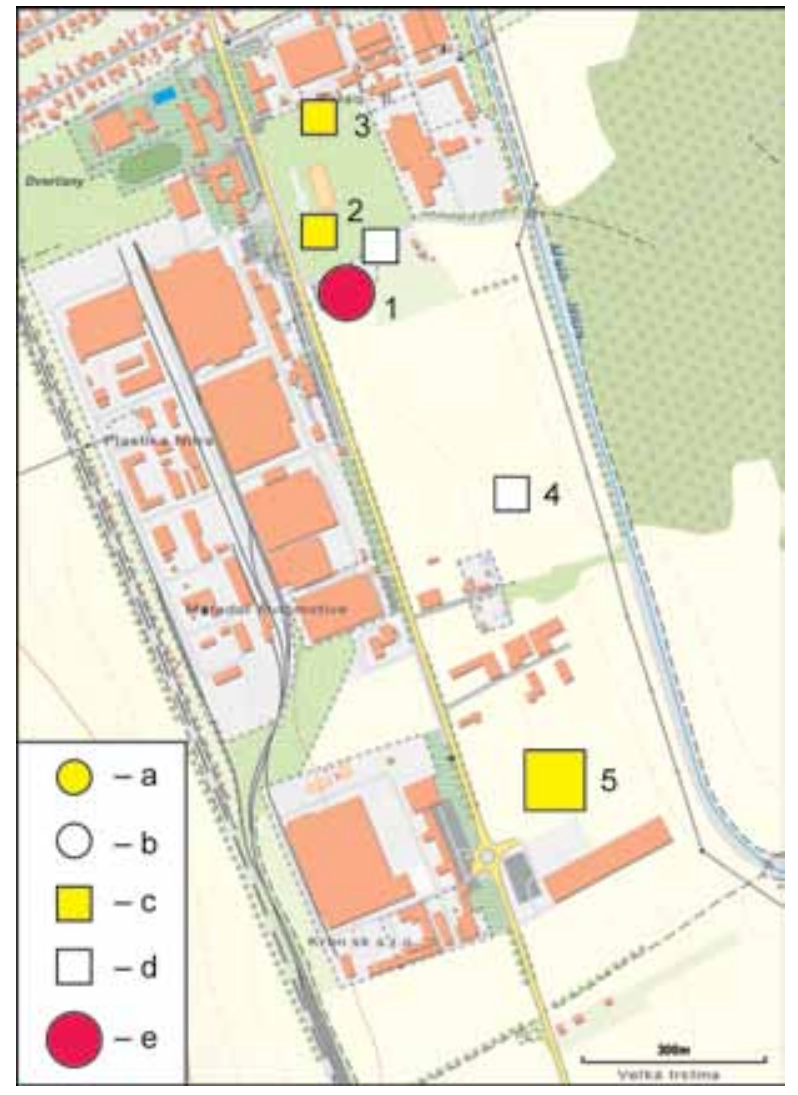

Obr. 1. Nitra-Dolné Krškany. Situovanie náleziska (e) s vyznačenými archeologickými lokalitami v bezprostrednej blízkosti uvádzanými v texte. Lengyelská kultúra: $\mathrm{a}$ - sídlisko; $\mathrm{b}$ - pohrebisko. Staršia doba bronzová: c - sídlisko; d - pohrebisko. 1 - TONEX; 2 - JRD; 3 - Plastika; 4 - terasa; 5 - Mühlbauer.

Orientácia pochovaného jedinca: Približne v smere JZZZ-SVVV, hlavou na Z, tvárou na JV.

Uloženie: Pochovaný dospelý jedinec bol uložený v silne skrčenej polohe na pravom boku. Pri hlave sa nachádzala spodná časț nádoby - miska (?). Ďalšia nádoba ležala pri chrbte. Mimo samotnej kostry ležal jeden stavec pri prstoch dolných končatín a jabíčko (patella) približne $20 \mathrm{~cm}$ severne od bedrovej kosti jedinca. Na lavej časti temena lebky sa zistili stopy po vyliečených poraneniach. V oblasti pravej spánkovej kosti sa zachoval umelý otvor s priemerom 1,4-3,3 cm, ktorý vznikol v perimortálnom období. Rozsiahly defekt $(7-10 \mathrm{~cm})$ bol už v čase odkryvu badatel'ný na lavej strane lebky jedinca v jej spánkovej časti.

Rozmery jamy: Dížka 108 cm, šírka 70 cm, híbka dna jamy od úrovne zachytenia $12 \mathrm{~cm}$, híbka od povrchu ornice pravdepodobne $42 \mathrm{~cm}$.

Zásyp: Hnedočierny.

Nálezy:

1. za hlavou jedinca uložený fragment dolnej časti nádoby (dno?, miska?), fragment sa nezachoval;
2. pri chrbte jedinca uložená spodná čast' gul'ovitej nádoby s vel'mi mierne hraneným maximálnym vydutím, pomerne zrnitá hmota s prímesou malých kamienkov, na vonkajšej strane hladká engoba a na nej stopy po červenom farbive; priemer dna 9,2 mm, maximálna šírka nádoby $17,5 \mathrm{~cm}$, maximálne vydutie vo výške $7 \mathrm{~cm}$, zachovaná výška 10,4 cm, ústie nezachované, hrúbka črepu v mieste vydutia $0,7-0,8 \mathrm{~mm}$ (obr. 2: 4);

3. v zásype jamy fragmenty bližšie neurčitelnej keramiky;

4. fragment $\mathrm{z}$ hladeného kosteného nástroja vyrobeného zo zvieracieho rebra (?) s rozmermi $4,9 \times 2,8 \mathrm{~cm}$, hrúbka 0,3 cm (obr. 2: 3);

5. v zásype v oblasti hrudníka jedinca obsidiánový nástroj mikrolitického charakteru, pravdepodobne súčast' zásypu, dížka 14 mm, šírka 4 mm (obr. 2: 1).

Rádiouhlíkové datovanie z ludských kostí - článku prsta:

Kalibrácia s využitím OxCal software. R_Date (5830, 40) Poz. 97323 (obr. 3).

$68,2 \%$ pravdepodobnost: 4767 pred n. $1 .(4,5 \%)$ 4756 pred n. 1.; 4742 pred n. 1. (2,0 \%) 4737 pred n. l.; 4729 pred n. 1 . (49,3\%) 4652 pred n. 1.; 4641 pred n. 1. $(12,5 \%) 4616$ pred n. 1 .

95,4 \% pravdepodobnost: 4790 pred n. 1. (94,3\%) 4580 pred n. 1.; 4567 pred n. 1. (1,1\%) 4558 pred n. 1 .

Nálezový inventár hrobu je aj v dôsledku jeho narušenia pomerne skromný. Z keramických milodarov je dôležitá rekonštruovaná spodná gulovitá čast' nádoby, ktorá indikuje príslušnost' k lengyelskej kultúre. Takmer mikrolitická čepel' vyhotovená z obsidiánu nemusela byt súčastou hrobovej výbavy, ale mohla sa dostat do hrobu spolu so zásypovou zeminou. Podobné nálezy čepielok poznáme aj z prostredia „rondelov“ (Mateiciucová 2017, 353). Spodná čast’ nádoby má početné paralely najmä vo fáze Lengyel I.

Rádiouhlíkové kalibrované datovanie - 47904580 pred n. 1. (95,4 \%) - umožnilo zásadné spresnenie pôvodného orientačného začlenenia hrobu do staršej fázy neskorej doby kamennej (Ruttkay 2004, 153, 296). S najväčšou pravdepodobnostou hrob môžeme zaradit už do záveru neolitu a spojit ho s počiatkami lengyelskej kultúry - s fázou Lengyel I (obr. 3; 4). Podobne, pravdepodobne trochu včasnejšie, sú zaradené aj tri rádiouhlíkovo datované vzorky z fázy Lengyel I vo Svodíne -4943-4700 pred n. 1. (Pavúk/Bátora 1995, 111). Datovanie hrobu z Dolných Krškán sa časovo kryje aj s rádiouhlíkovým zaradením uhlíkov zo sídliska Polgár-Csőszhalom, z mladšej sídliskovej fázy II z rokov 4845-4755 pred n. 1. a z fázy III z rokov 4891-4472 pred n. 1. (Raczky/Anders 2010, 360, 364, 365, 368). Pomerne jasne 


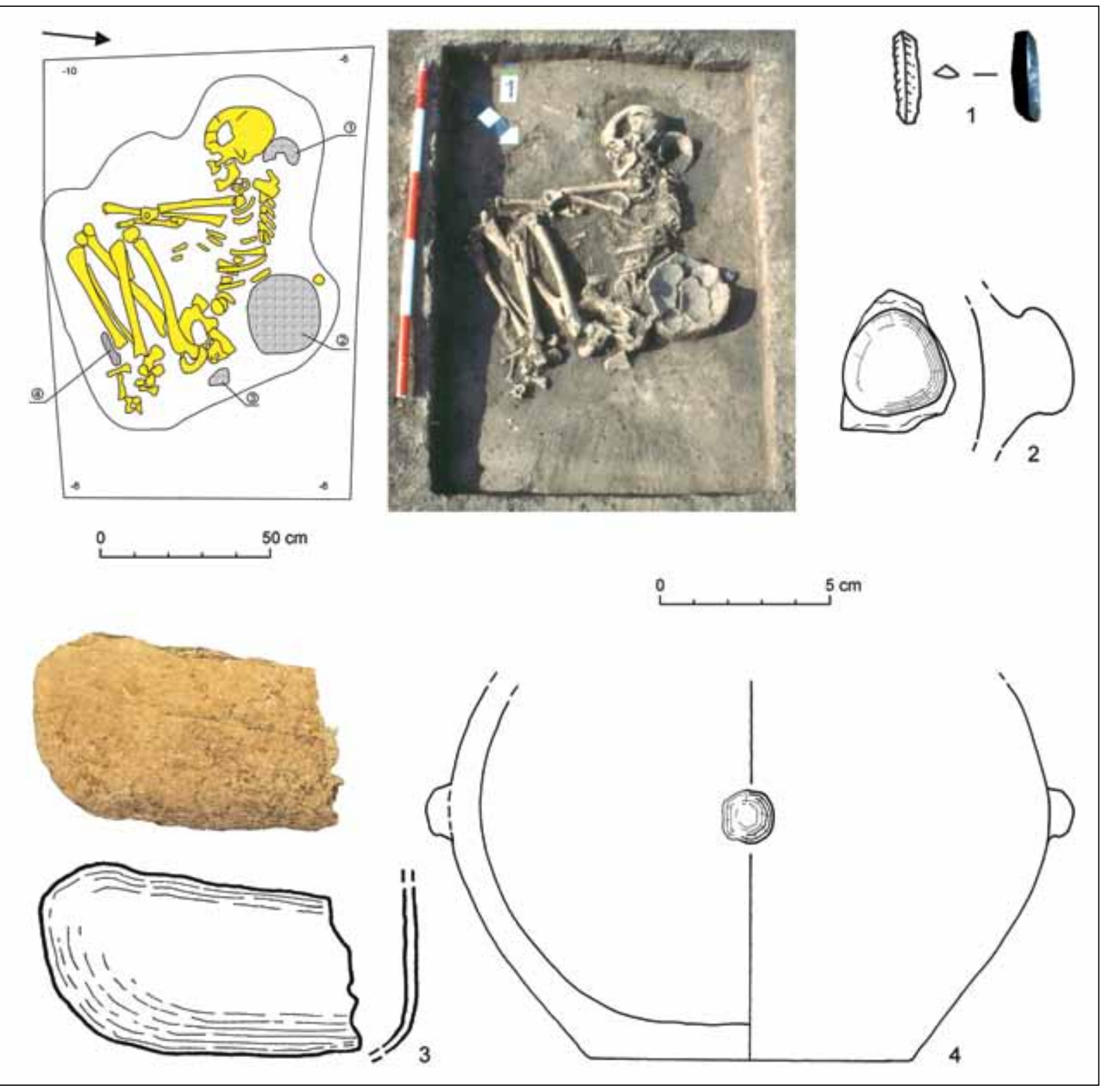

Obr. 2. Nitra-Dolné Krškany, hrob 1 (kresby nálezov E. Bakytová, foto a kresba plánu M. Ruttkay).

korešponduje aj s fázou Ia a čiastočne Ib moravsko-rakúskej skupiny s mal'ovanou keramikou (Stadler) Ruttkay 2007, obr. 1; Kuča a i. 2012, 106). Dozaista by bolo zaujímavé porovnanie s Protolengyelom, ktorý niektorí bádatelia absolútne datujú tiež do obdobia po roku 4800 pred n. 1. (Stadler/Ruttkay 2007, 132), tu však rádiouhlíkovo datovanými vzorkami z oblasti západného Slovenska nedisponujeme. Záver neolitu je obdobie, kedy sú v Karpatskej kotline známe nielen pomerne rozsiahle pohrebiská (Farkaš 1999, 219; Němejcová-Pavúková 1986), ale časté sú aj ojedinelé hroby, prípadne malé skupiny hrobov priamo na sídliskách, nezriedka tiež pohreby $\mathrm{v}$ rôznych sídliskových jamách. Zároveň sa $\mathrm{v}$ období medzi
4850/4750-4650/4500 pred n. l. budujú mohutné kruhové priekopové útvary - rondely (Neubauer 2017).

Už v starších fázach lengyelskej kultúry je časté, že sa hroby/pohreby objavujú aj na sídliskách, prípadne v ich blízkosti (Lenneis Hrsg. 2017, 314). Tento jav pretrváva až do mladších fáz lengyelskej kultúry. Pohrebné praktiky sú v tejto dobe značne neustálené. Časté sú pohreby v neštandardnej polohe - na bruchu, na chrbte, odstránené časti tela (často hlava), druhotne porušené telá, žiarové hroby a podobne (Farkaš 1999, 119). Žena z Dolných Krškán bola pochovaná najčastejšie preferovaným spôsobom tohto obdobia - s orientáciou $\mathrm{Z}-\mathrm{V}, \mathrm{v}$ skrčenej polohe a s pohladom na JV. 


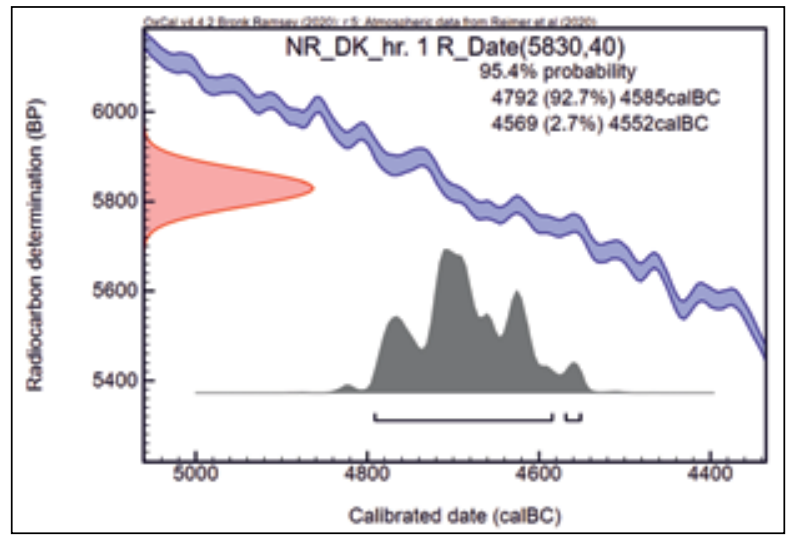

Obr. 3. Nitra-Dolné Krškany. Rádiouhlíkové datovanie hrobu 1.

Z fázy Lengyel I sú nálezy hrobov v nitrianskom regióne výnimočné, a to napriek tomu, že región Nitry je na hrobové nálezy z iných vývojových fáz lengyelskej kultúry pomerne bohatý (Pavúk 1993; Pavúk/Bátora 1995, 121-124; Pažinová/Bistáková 2013; Ruttkayová 1998). V bezprostrednom susedstve analyzovanej lokality $\mathrm{v}$ priestore bývalého JRD je doložené sídlisko želiezovskej skupiny a lengyelskej kultúry (Kolník 1958). Jedinečné sú už protolengyelské pohrebiská lužianskej skupiny z Lužianok (Novotný 1962, 244) a z Nitry-Mlynáriec (Budinský-Krička 1947, 60). Na druhej strane registrujeme väčší počet pohrebísk, ale najmä hrobov na sídliskách z obdobia ludanickej skupiny lengyelskej kultúry. Patrí sem napríklad pohrebisko a pohreby v sídliskových jamách v Branči (18 hrobov; Lichardus/Vladár 1964), sídlisko a 12 hrobov zo staršej fázy ludanickej skupiny vo Výčapoch-Opatovciach (Porubský 1955, 437-443; Pavúk/Bátora 1995, 121) a 30 hrobov v Jelšovciach $\mathrm{s}$ rádiouhlíkovým datovaním v rozpätí rokov od $5520 \pm 67$ do $5210 \pm 50$ pred n. 1. (Pavúk/Bátora 1995, 50, 110). V rokoch 2009 a 2010 sa preskúmali hroby, respektíve pohreby $\mathrm{v}$ jamách na sídlisku Nitra-Selenec s rádiouhlíkovým datovaním $\mathrm{v}$ rozpätí rokov od $5480 \pm 40$ do $5260 \pm 40$ pred n. 1. (Gabulová, $v$ tlači), 7 hrobov v Nitre-Mlynárciach (Gabulovál Kuzma 2015; Kuzma/Jakab/Kopčeková 2010), 2 hroby na sídlisku v Lefantovciach (Kujovský/Žebrák 1984), hrob v Čabe (Novotný 1958) a hroby v Nitre na Martinskom vrchu (Lichardus/Vladár 1970, 395, 396). Viaceré antropologické analýzy skeletov zo sídliskových objektov a hrobov naznačujú, že poranenia, zahojené rany a doklady stresu sú na pohrebiskách lengyelskej kultúry pomerne časté (Gabulová/Kuzma 2015, 194, 195; Lenneis Hrsg. 2017, 314-319). Z tohto

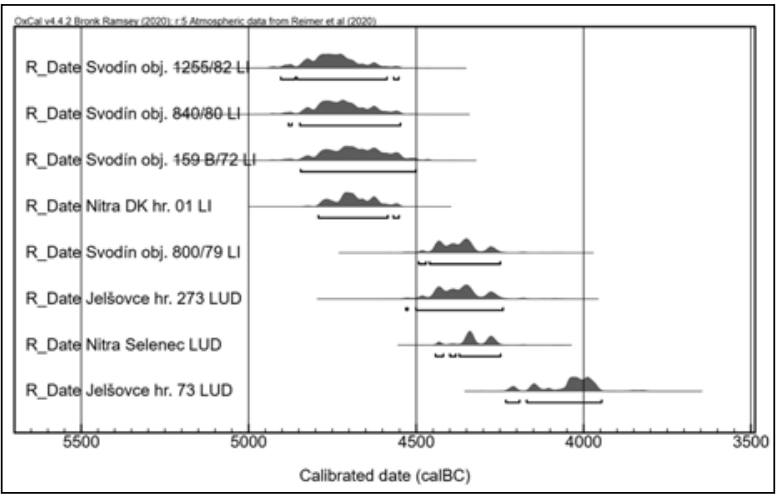

Obr. 4. Výber rádiouhlíkových dát lengyelskej kultúry na západnom Slovensku (podla Gabulová, v tlači; Němejcová-Pavúková 1986, 155; Pavúk/Bátora 1995, 110, 111).

rámca nevybočuje ani hrob č. 1 v Dolných Krškanoch, ktorý mal podla predbežného antropologického vyhodnotenia násilne porušenú l’avú stranu lebky (Jakab 2005 a ústna informácia Júliusa Jakaba).

Hroby datované do fázy Lengyel I sú však v oblasti Nitry výnimočné, preto hrob č. 1 z Dolných Krškán by mohol v budúcnosti pomôct' pri objasňovaní migračných a osídlovacích procesov v rámci rozvíjajúcej sa lengyelskej kultúry a zároveň môže byt dôležitým prvkom pri budúcich genetických ${ }^{2}$ a izotopových výskumoch dobových populácií.

\section{OBJEKT Č. 16 - ARCHEOLOGICKÝ KONTEXT, OPIS NÁLEZOV A VYHODNOTENIE}

V záverečných dňoch výskumu sa pristúpilo k odkryvu posledného identifikovaného objektu. Najprv sa zdalo, že ide o bežnú zásobnú jamu. $\mathrm{V}$ spodnej časti sa narazilo na ludské kostry (obr. 5-8). Antropologické údaje a fotografie rekonštruovaných lebiek sú výsledkom analýzy J. Jakaba (2005 a ústna informácia).

Samotný objekt mal tvar kužela s úzkym hrdlom a širokou základňou.

Pôdorys: Kruhový.

Rozmery: Priemer v úrovni jednoznačného zachytenia (v híbke $45 \mathrm{~cm}$ ) $90 \mathrm{~cm}$, priemer pri dne (t. j. v híbke $100 \mathrm{~cm}$ od úrovne zachytenia) $205-218 \mathrm{~cm}$

Výplň a nálezy: na dne jamy, resp. tesne nad dnom sa odkrylo 5 kostier - štyri uložené cez seba a d’alšia v západnej časti v polohe na bruchu. V zásype

\footnotetext{
2 Vzorky sú na analýze DNA v laboratóriu Department of Anthropology Universität Wien (Ron Pinhasi).
} 
jamy neboli viditel'né zásadnejšie zvrstvenia. Objekt obsahoval zlomky bližšie nedefinovatelnej neolitickej keramiky, zlomky kamenných úštepov a nástrojov, ako aj fragmenty $\mathrm{z}$ jemne plavenej keramiky s čiernym leskom na povrchu, medzi nimi fragment okraja s dvoma líniami šnúrovej výzdoby (nitrianska kultúra; obr. 7: 5).

\section{Skelet č. 1}

Dieta (infans III/6-7 rokov) bolo uložené na jedincovi č. 2 - hlavou $v$ jeho lone opretou o lavé lýtko, dolné končatiny nad pravým ramenom a predlaktím kostry č. 2 (obr. 5; 6; 8).

Orientácia: SSZ-JJV, hlavou na SSZ.

Uloženie: Na chrbte vo vystretej polohe, lavá noha rozrušená a kosti predkolenia nájdené $\mathrm{v}$ druhotnej polohe v juhovýchodnej časti jamy, pravá noha vystretá, lavá ruka vystretá a upažená doprava ponad pravé rameno, pravá ruka v lakti skrčená s dlaňou pri krku, hlava vyvrátená dozadu. Na pravej strane lebky otvor, pravdepodobne po perimortálnom zranení hrotitým predmetom.

\section{Nálezy:}

Na lavej strane lebky sa nachádzal medený drôtený krúžok (obr. 7: 3) a na pravej strane lebky medený drôtený krúžok so spätnou slučkou (obr. 7: 4). Nad krčným stavcom sa našla jedna ozdoba $\mathrm{z}$ kančieho kla (obr. 7: 2) a oproti nej pod stavcami druhá (obr. 7: 1).

1. medený krúžok so spätnou slučkou, priemer krúžku 2,5 cm (obr. 7: 4);

2. medený krúžok, priemer krúžku 1,9 cm (obr. 7:3);

3. ozdoba $\mathrm{z}$ kančieho kla s otvorom na oboch koncoch, rozpätie $11,8 \mathrm{~cm}$, priemer otvorov $0,5 \mathrm{~cm}$ a $0,25 \mathrm{~cm}$ (obr. 7: 1);

4. ozdoba z kančieho kla, na jednom konci otvor zachovaný kompletne a na druhom čiastočne, rozpätie $8,9 \mathrm{~cm}$, priemer zachovaného otvoru 0,35 cm (obr. 7: 2).

Rádiouhlíkové datovanie z ludských kostí:

Kalibrácia s využitím OxCal software, OxCal v4.2.3 Bronk Ramsey (2013); r:5, IntCal13 atmospheric curve (Reimer a i. 2013).

R_Date $(3570,35)$.

$68,2 \%$ pravdepodobnost: 1972 pred n. 1. (68,2 \%) 1882 pred n. 1 .

$95,4 \%$ pravdepodobnost: 2026 pred n. 1. (84,2\%) 1871 pred n. 1.; 1846 pred n. 1. (6,6\%) 1812 pred n. 1.; 1803 pred n. $1 .(4,6 \%) 1777$ pred n. 1 .

\section{Skelet č. 2}

Dospelý muž vo veku maturus II/50-60 rokov ležal nad skeletmi č. 3 a 5 , na ňom bol uložený jedinec č. 1 (obr. 5; 6). Bez nálezov.
Orientácia: J-S, hlavou na J, tvárou na V.

Uloženie: $\mathrm{V}$ polohe na chrbte, nohy v žabej polohe, ruky v lakti pokrčené a dlaňami pri hlave (v nepravom adoračnom geste), lavá ruka vedla tela a v lakti pokrčená prstami smerujúca $\mathrm{k}$ brade, pravá horná končatina uložená v tvare písmena $\mathrm{V}$ s dlaňou vyhnutou tak, že prsty smerujú k brade, špičky nôh napnuté a smerujú na $S$.

Rádiouhlíkové datovanie z l'udských kostí:

Kalibrácia s využitím OxCal software, OxCal v4.2.3 Bronk Ramsey (2013); r:5, IntCal13 atmospheric curve (Reimer a i. 2013).

R_Date (3550, 35).

$68,2 \%$ pravdepodobnost: 1947 pred n. 1. (52,1\%) 1877 pred n. 1.; 1841 pred n. 1. (9,6\%) 1821 pred n. 1.; 1796 pred n. $1 .(6,6 \%) 1782$ pred n. 1 .

95,4 \% pravdepodobnost: 2011 pred n. 1. (1,6\%) 2000 pred n. 1.; 1977 pred n. 1. (93,8 \%) 1771 pred n. 1 .

\section{Skelet č. 3}

Dieta (infans III/10-11 rokov) bolo uložené na dno jamy tak, že ležalo pod hornou častou tela a hlavou jedinca č. 2. Lebka dietała sa opierala o lebku jedinca č. 4 (obr. 5; 6). Bez nálezov.

Orientácia: JJJV-SSSZ, hlavou na J, tvárou na V.

Uloženie: Dolné končatiny v extrémne skrčenej polohe na lavom boku, ruky mierne pokrčené, dlaňami pri kolenách, hlava akoby násilne vytočená k východu.

\section{Skelet č. 4}

Dospelý muž vo veku adultus I/20-30 rokov bol uložený v západnej časti jamy, v polohe na bruchu ležal na jej dne, respektíve smerom $\mathrm{k}$ jej okraju (obr. 5; 6). Bez nálezov.

Orientácia: JJJV-SSSZ, hlavou na J, pohladom do zeme.

Uloženie: Hlava mierne vyvrátená dohora (násilne?), pravá a lavá ruka v lakti pokrčené a pri tele (dlaň pri ramene, resp. pod telom), lavá noha silne skrčená a pravá mierne pokrčená, pravé predlaktie bolo uložené zjavne neanatomicky, viaceré zuby sa našli „padnuté" v priestore medzi tvárovou častou lebky a okrajom jamy, resp. medzi článkami prstov, čo naznačuje, že priestor bol dlhšiu dobu dutý (nezasypaný).

\section{Skelet č. 5}

Dieta (infans III/7-9 rokov) bolo uložené na dne jamy $\mathrm{v}$ jej východnej časti, pod panvou a pravou nohou jedinca č. 2 (obr. 5; 6). Bez nálezov.

Orientácia: JVVV-SZZZ, hlavou na V, tvárou na S. Uloženie: v skrčenej polohe na pravom boku, lavá ruka smeruje k nohám a pravá je dlaňou uložená $\mathrm{k}$ čelu. 

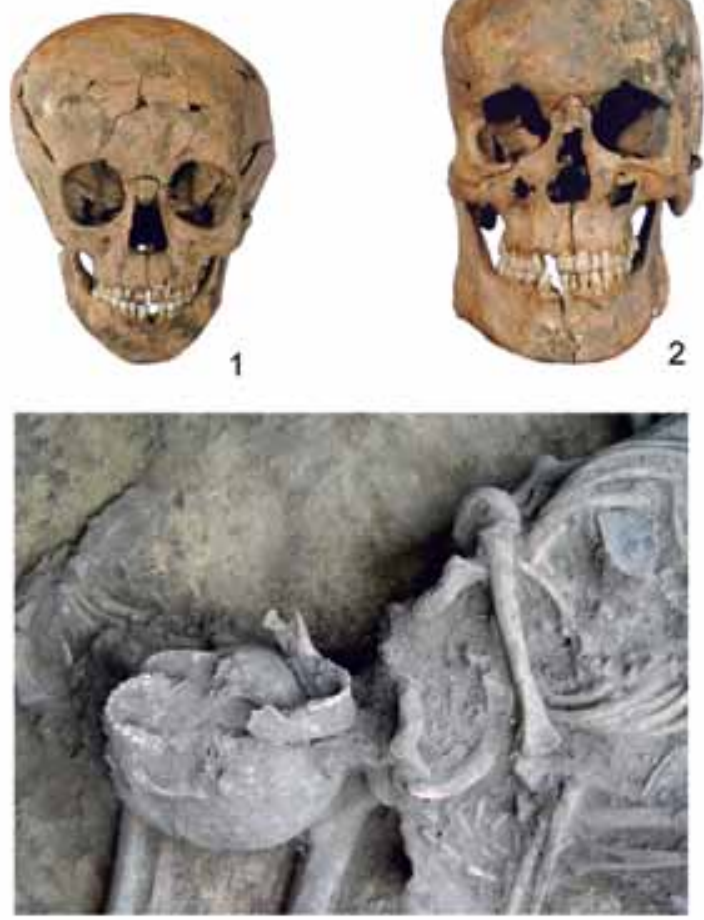

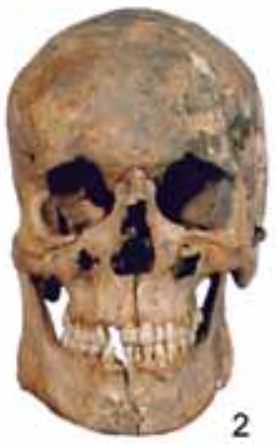

2 5
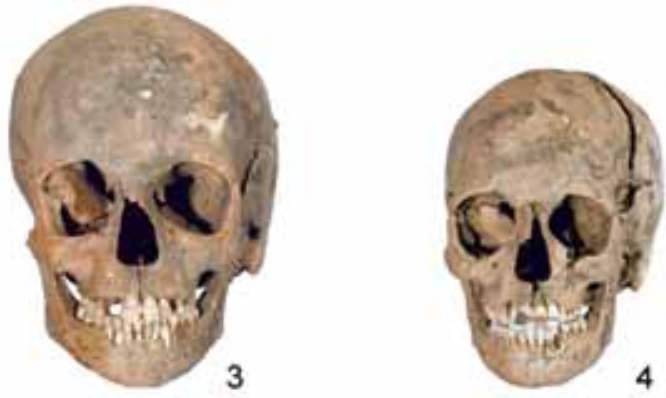

4

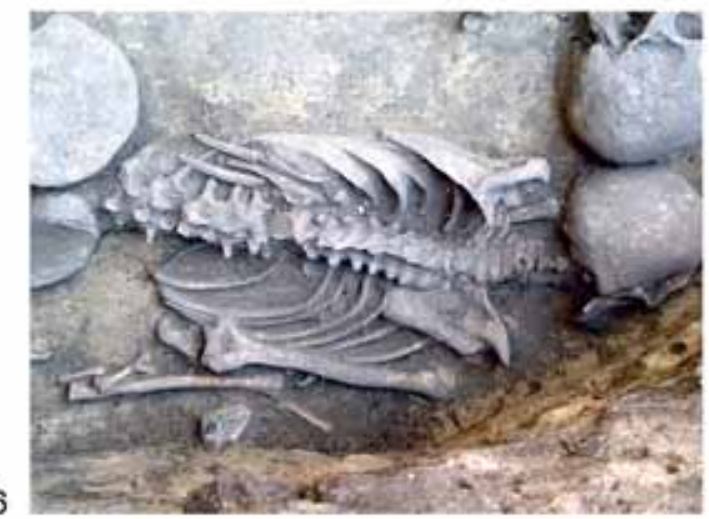

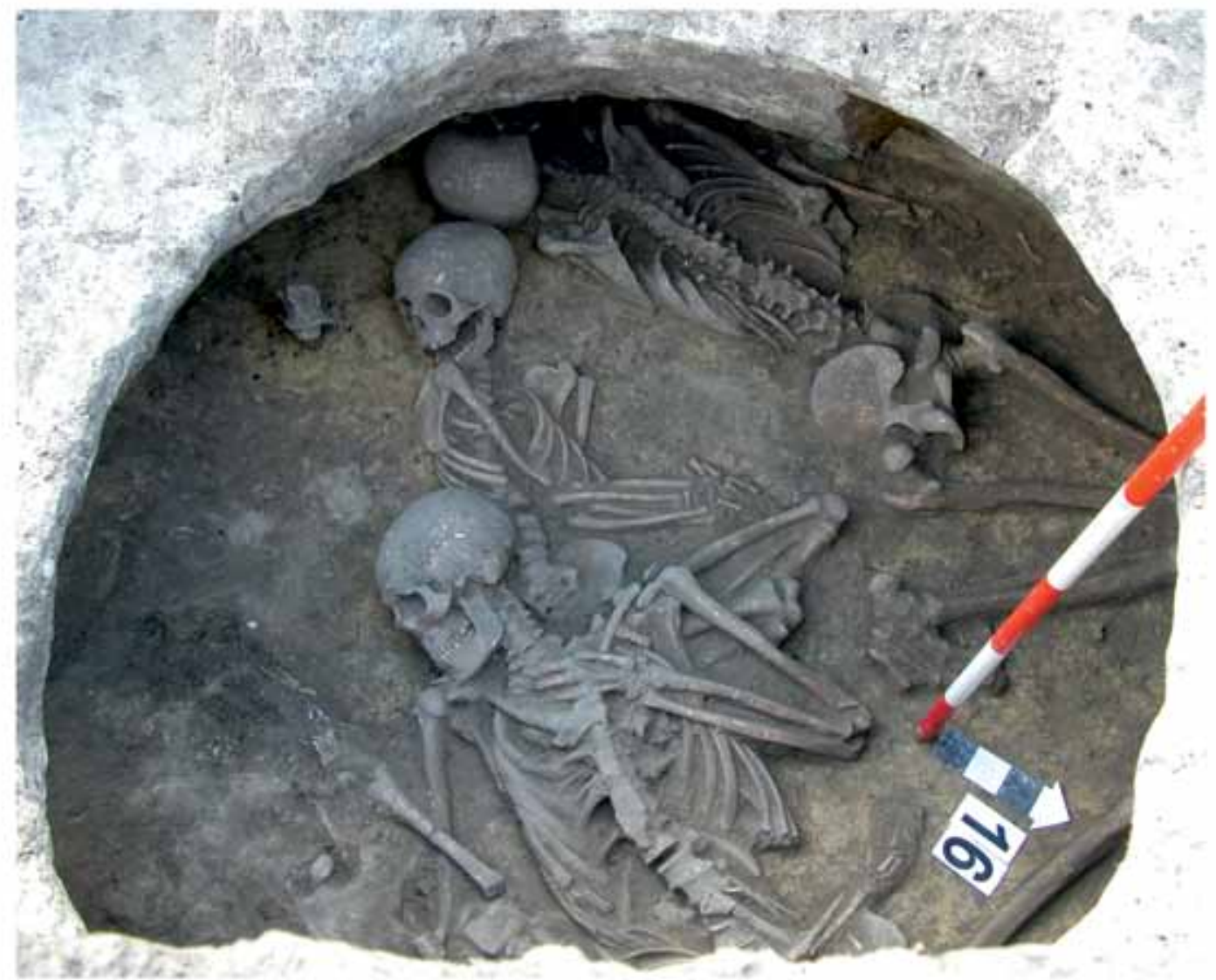

Obr. 5. Nitra-Dolné Krškany, objekt 16. 1,5-skelet 1; 2 - skelet 2; 3, 6- skelet 4; 4- skelet 3; 7 - skelety 2, 3, 4 (foto J. Jakab, M. Ruttkay). 


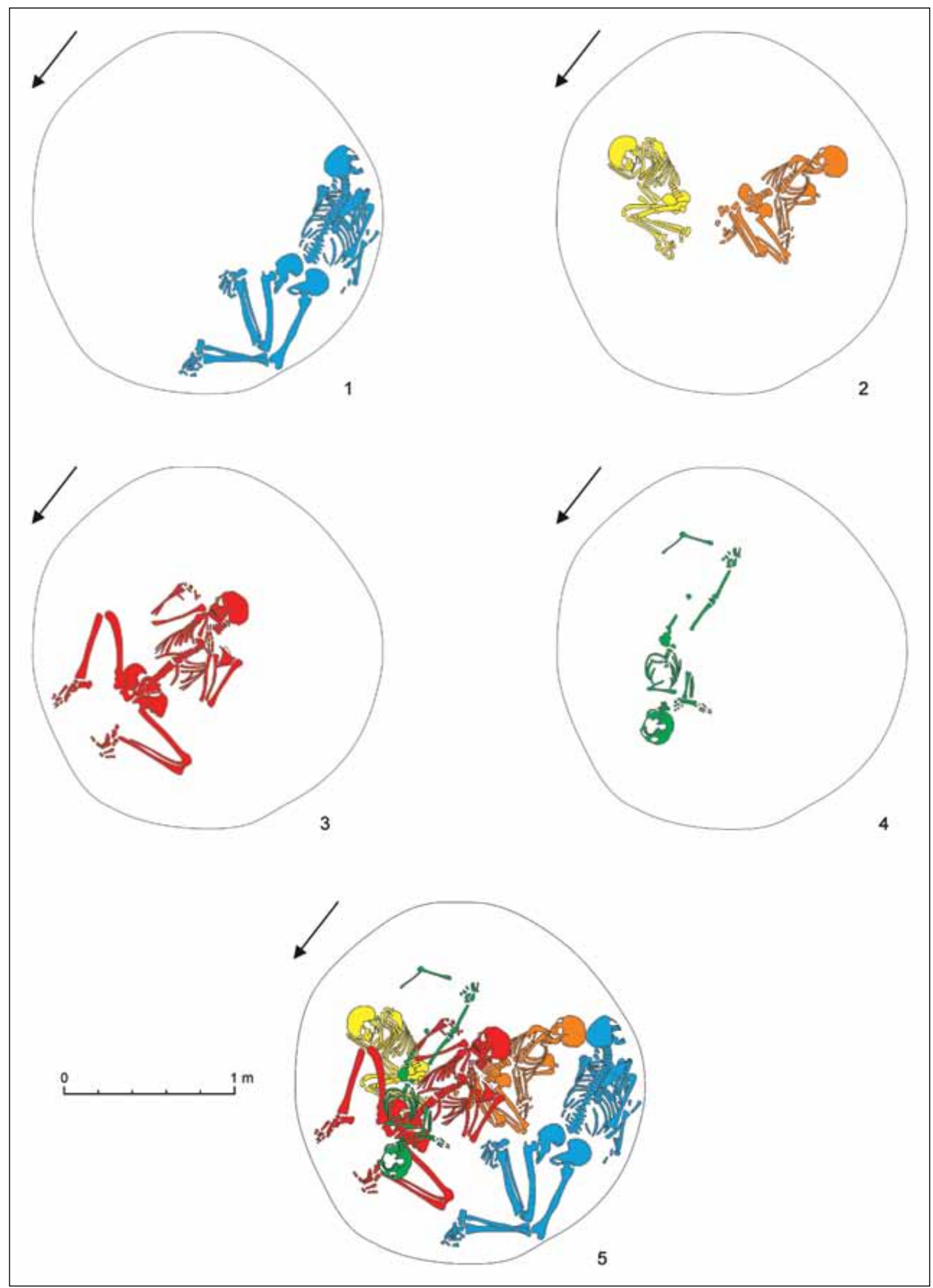

Obr. 6. Nitra-Dolné Krškany. Skelety na dne jamy a plány s postupom uloženia ludských jedincov v objekte 16, od č. 1 po č. 4 (autor M. Ruttkay, prekreslil B. Balžan). 


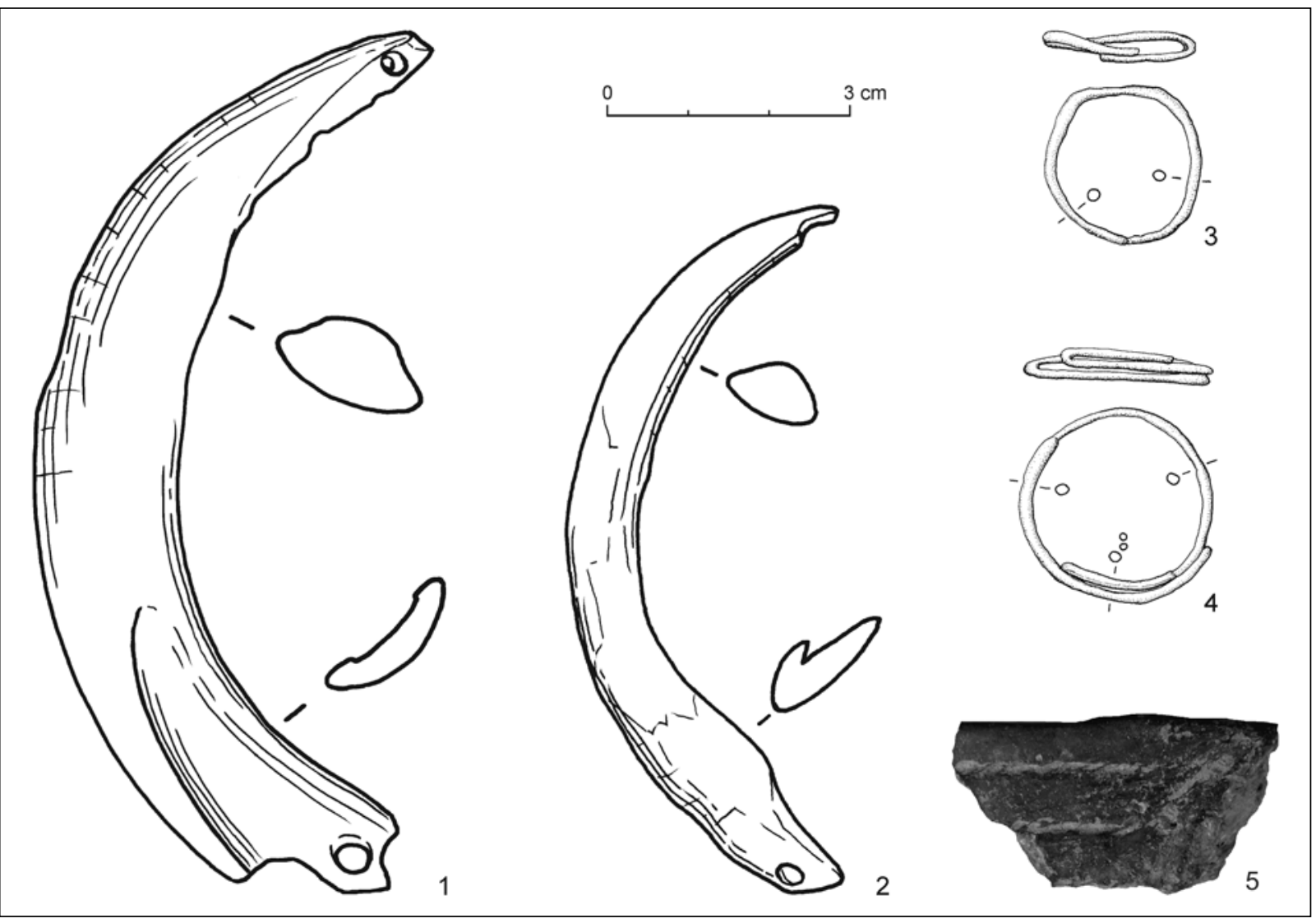

Obr. 7. Nitra-Dolné Krškany. Nálezy z objektu 16. 1-4 - nálezy pri skelete č. 1; 5 - črep zo zásypu objektu (kresby a foto E. Bakytová).

Nálezy

V Dolných Krškanoch sa v objekte č. 16 pri skelete č. 1 našli dva kančie kly - vel'ký a malý exemplár. Patria k pomerne častej výbave najmä mužských hrobov z viacerých kultúr staršej doby bronzovej $\mathrm{v}$ širokom geografickom priestore od Potisia po Polabie (Bátora 2006, 175; Benkovsky-Pivovarovál Chropouský 2015, 94; Ondráček 1963, 405-415; Vladár 1973, 156). V hroboch sa nachádzajú v rôznom počte, niekedy s možnostou vloženia jeden do druhého. Objavujú sa aj v detských (chlapčenských?) hroboch (Bernard 2005, 104, mapa 43) a výnimočne ich nachádzame aj v hroboch dospelých žien (napríklad Branč: hroby 223, 232; Vladár 1973). Na západnom Slovensku sú časté najmä v nitrianskej kultúre, ale vyskytujú sa aj v únětickej či mad’arovskej kultúre (Bátora 2000, 516; Benkovsky-PivovaroválChropovský 2015, 94; Točík 1979). Ich interpretáciu komplikuje aj skutočnost', že zaznamenávame pomerne vel'kú rozmanitost' $\mathrm{v}$ mieste ich uloženia $\mathrm{v}$ hrobe, ako aj v ich počte (Bernard 2005, 104). Podla niektorých autorov mohli slúžit ako symbol zdatného lovca, čo však v prípade detských hrobov asi neplatilo, inoke- dy ako symbol vyššieho spoločenského postavenia, alebo ako ochranná nášivka na ramenách, či rukách. Kedže sa jeden exemplár v prípade jedinca č. $1 \mathrm{v}$ objekte 16 z Dolných Krškán našiel na prednej strane tela a druhý na zadnej strane krčnej časti chrbtice, je pravdepodobné, že $\mathrm{v}$ tomto prípade boli kančie kly použité bud' ako nákrčník, alebo ako ozdoba, spínadlo či ochrana hornej časti odevu v priestore krku a ramena.

Na lebke skeletu č. 1 sa našli dva medené krúžky - jednoduchý a so spätnou slučkou. Podobné krúžky sa zväčša nachádzajú v ženských hroboch, prípadne v hroboch detí, ktoré by mohli byt podla orientácie skeletu ženského pohlavia. Výnimočne sa objavujú aj v mužských hroboch (Benkovsky-Pivovarová/Chropovský 2015, 71-73; Vladár 1973, 146). Oba kruhové šperky boli vyrobené temer z čistej medi $(93,216 \%$ a $87,656 \%$ ), bez cínu i arzénu s malým zastúpením antimónu $(1,137 \%$ a $1,214 \%)$ a striebra $(1,769 \%$ a $2,605 \%)$.

Podobné drôtené kruhové šperky sa používali vo viacerých kultúrach staršej doby bronzovej, najmä v nitrianskej a únětickej kultúre, ale ich kultúrna priekaznost̉ je minimálna. To, že sú vyrobené 


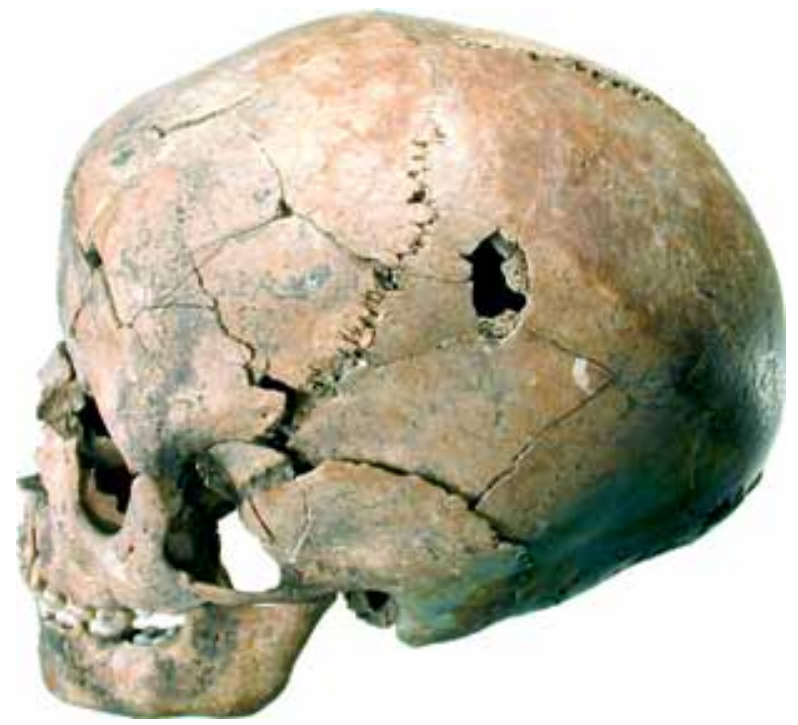

Obr. 8. Nitra-Dolné Krškany. Detail poranenia na lebke skeletu č. 1 z objektu 16 (foto J. Jakab).

z medi, naznačuje ich časové zaradenie skôr do staršieho úseku staršej doby bronzovej.

\section{Chronológia}

Už pri prvom zverejnení nálezu bol objekt č. 16 predbežne priradený k nitrianskej kultúre. Rádiouhlíkové datovanie dvoch skeletov vykonané v laboratóriu Poznaň toto zaradenie spresňuje. Skelet č. 1 je datovaný do obdobia $3570 \pm 35$ pred n. 1 . a skelet č. 2 do obdobia $3550 \pm 35$ pred n. 1. (obr. 10). Znamená to absolútne datovanie skeletu č. $1 \mathrm{~s}$ najväčšou pravdepodobnostou medzi roky 2027 a 1775 pred n. 1. (95,4 \%) a skeletu vekovo staršieho jedinca č. 2 medzi roky 2019 a 1767 pred n. 1. (95,4 \%). Tieto údaje sa dajú vel'mi dobre korelovat s okolitými pohrebiskami v Branči a Jelšovciach (obr. 9), pričom absolútne dáta $\mathrm{z}$ pohrebiska $\mathrm{v}$ Jelšovciach akoby nadväzovali na staršie dáta $\mathrm{z}$ pohrebiska $\mathrm{v}$ Branči. J. Bátora $(2000,510)$ datuje prechodný nitriansko-únětický horizont na pohrebisku v Jelšovciach do rozpätia rokov 1930-1870 pred n. 1. (Gerloff 1993; Görsdorf 2000, 567). Tu však treba mat' vždy na pamäti, že datovaná je iba minimálna čast̉ hrobov. S takmer zhodným datovaním sa stretávame aj na lokalite Nitra-Selenec (2020-1774 pred n. 1., pri $95,4 \%$ pravdepodobnosti; Gabulová, v tlači) a o niečo staršie je datovaný skelet zo sídliska $\mathrm{v}$ nive rieky Nitra v Zbehoch (2030-1826 pred n. 1., pri 95,4 \% pravdepodobnosti; Hukelováa a i. 2020). Výrazne staršie je pohrebisko nitrianskej kultúry v Nitre na Svätoplukovom námestí (2286-2036 pred n. 1., pri 95,4\% pravdepodobnosti; Ruttkay 2018). Ako vidiet' z grafu (obr. 9), kde sú zhromaždené základné aktuálne známe kalibrované dáta $z$ oblasti Nitry a výberovo aj zo susedných regiónov, dáta z Dolných Krškán naznačujú uloženie jedincov do jamy najpravdepodobnejšie v čase klasickej, prípadne najmladšej nitriansko-únětickej fázy nitrianskej kultúry (podla členenia Točík/Vladár 1971). Objekt č. 16 je z časového a kultúrneho hladiska súčastou kultúrneho komplexu Mierzanowice-Nitra-Koštany.

Uvedené datovanie $\mathrm{v}$ podstate korešponduje so stredovým zaradením aj v rámci rozpätia moravských lokalít, napríklad Hulín 1, Hulín 3, Holešov, Osek nad Bečvou (Peška/Tajer 2017, tab. I; 2). V Rakúsku sa s týmto datovaním kryje napríklad aj rádiouhlíkové datovanie lokality Schleinbach 2084-1627, resp. 1950-1850 pred n. l. (Pany-Kucera a i. 2020,17). V tomto kontexte vyznieva mierne nejasné porovnanie s nedávno publikovaným pohrebiskom v Šoporni (Bartík 2018, 39), kde sú nálezy klasického stupňa/fázy únětickej kultúry datované medzi roky 1980-1860, čiže do obdobia, kam tradične patrí nitrianska kultúra. Tieto komplikácie ukazuje aj krátka sumarizácia aktuálnych rádiouhlíkových dát zo súvekých pohrebísk a sídlisk (obr. 9). Potvrdzujú sa určité nezrovnalosti medzi absolútnymi dátami a zaužívanou relatívnou chronológiou, prípadne sa nastolujú otázky ohladne paralelného fungovania nitrianskej a únětickej kultúry. V poslednom období na túto skutočnost' upozorňujú viacerí autori (Benkovsky-Pivovarová 2011; Peška/Tajer 2015).

\section{Kult alebo konflikt $\mathrm{v}$ komunite?}

To, že skelety v spodnej časti objektu boli viac-menej neporušené, znamená, že jedinci museli byt do jamy uložení bud' naraz, alebo vo velmi krátkom časovom slede. Spodní jedinci boli položení priamo na dno objektu. Preto je takmer isté, že jama bola v čase uloženia jedincov prázdna (nezasypaná, neprisypaná). Rozhodnút, či jama bola určená cielene pre uloženie mŕtvych jedincov, alebo bola pôvodne vyhíbená na iné účely (typologicky ide o tvar zásobnej jamy), nie je možné. Posun kostí (celej časti končatiny) mimo ich pôvodnej polohy je s najväčšou pravdepodobnostou možné spájat' s neskoršou dekompozíciou. Naznačuje to, že objekt nebol po vložení jedincov do jamy dlhšie obdobie zasypaný.

Pri rekonštrukcii pohrebu je potrebné brat do úvahy úzky valcovitý otvor a nevysokú kuželovitú čast̉ jamy - v podstate maximálna výška dolnej časti v mieste otvoru je iba $100 \mathrm{~cm}$. Preto je len tažko predstavitelné, že by sa $\mathrm{v}$ jame mohol hýbal viac ako jeden človek ukladajúci telá do jamy. Taktiež to jasne dokazuje, že telá nemohli byt do jamy vhodené, ale že boli do nej cielene uložené. To platí 
osobitne o skelete č. 4, ktorý by na prvý pohlad mohol vyzerat' ako vhodený. Jeho poloha na bruchu s vyklonenou hlavou (zlomené väzy?) musela mat'

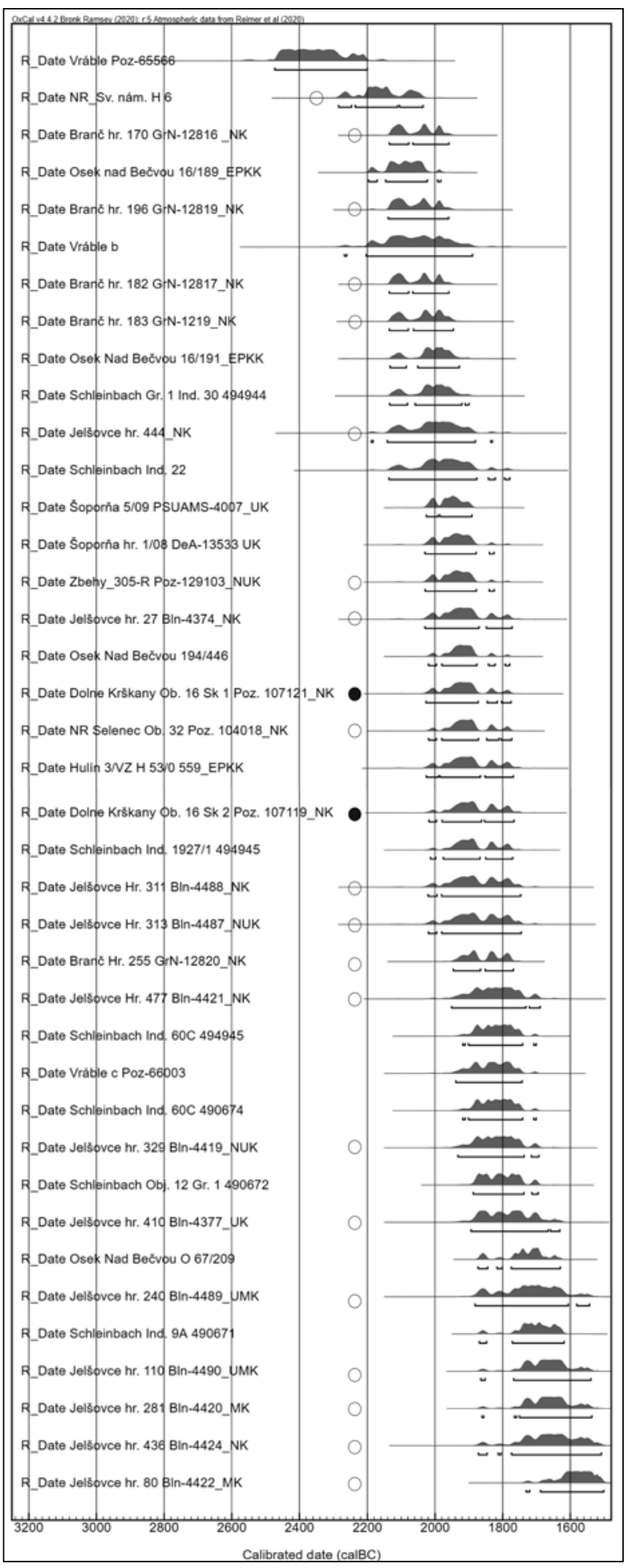

Obr. 9. Nitra-Dolné Krškany, objekt 16. Výber rádiouhlíkových datovaní ludských skeletov a zvieracích kostí zo staršieho úseku staršej doby bronzovej. Plný kruh - lokalita TONEX; prázdny kruh - nitrianska oblast'. v sebe jednoznačnú symboliku. Do pozície, v akej sa jedinec č. 4 nachádzal, bol dozaista uložený zámerne. Podobnú pozíciu má nedávno preskúmaný pohreb v jame na sídlisku nitriansko-únětického stupňa na stavenisku infraštruktúry $v$ priemyselnom parku Nitra-Sever v katastri obce Zbehy (Hukelová a i. 2020). Paralela je známa napríklad aj zo Žlkoviec - skelet č. 2 v objekte 295 (kuželovitá jama zo staršej doby bronzovej; Pavúk 1984, 176). S ohl'adom na skutočnost', že pri jedincoch č. 2-5 z Dolných Krškán sa nenašli žiadne nálezy (ani súčasti odevu, ani šperk), by sme mohli uvažovat' o tom, že títo jedinci mohli byt na rozdiel od jedinca č. 1 pochovaní aj bez odevu.

Je vel'mi pravdepodobné, že ako prvý bol do objektu č. 16 umiestnený jedinec č. 4 (obr. 6: 1). Ak si totiž predstavíme, že by jedinci č. 3 a 5 ležali na dne jamy už predtým, technicky by bolo takmer nemožné uložit na dané miesto aj jedinca č. 4. Okrem toho, hlava jedinca č. 3 sa zhora opierala o hlavu jedinca č. 4. To znamená, že ako druhý, resp. tretí v poradí boli vložení jedinci č. 3 a 5 , cielene chrbtom k sebe (obr. 6: 2). Vytvorili tak jasnú bipolárnu situáciu. Podla uloženia na pravom a lavom boku mohlo íst' o dievča a chlapca. Následne bol jedinec č. 2 doslova majestátne - ako centrálny bod priestoru objektu - uložený do stredu jamy v žabej polohe s rukami v nepravom adoračnom geste (obr. 6: 3). Na záver bolo na jedinca č. 2 uložené zabité dieta (skelet č. 1), ktoré ako jediné malo na sebe aj nálezy (obr. 6: 4). Uloženie vo vystretej polohe na chrbte je v rámci staršej doby bronzovej a nitrianskej kultúry zriedkavé, nie však výnimočné. Kombinácia kančích klov a medených krúžkov by azda mohla naznačovat' skôr mužské ako ženské pohlavie pochovaného jedinca.

Doslova ústrednou postavou analyzovaného objektu je muž (skelet č. 2) ležiaci v žabej polohe s rukami v adoračnom geste. Podobný rítus má dlhovekú tradíciu, azda siahajúcu až do obdobia okrových hrobov, jamovej či katakombovej kultúry (Ecsedy 1979). Paralely k nemu však nachádzame aj v prostredí kultúr staršej doby bronzovej na západnom Slovensku. Na pohrebisku v Pate sa v hrobe 33 našli pozostatky dvoch dospelých jedincov a jednej ženy, pričom ústredný jedinec bol pochovaný na chrbte s nohami $\mathrm{v}$,žabej polohe" a s rukami v adoračnom geste (Cheben 2012, 123 a osobná informácia). Pochovávanie v tzv. žabej polohe nie je výnimočné $\mathrm{v}$ predchádzajúcich obdobiach na západnom Slovensku. Vhodným príkladom zo starších období (lengyelská kultúra) je objekt 337/74 vo Svodíne, kde pochovaný jedinec je uložený na chrbte s rukami $\mathrm{v}$ adoračnom geste, pričom lavé predlaktie vykazuje známky zahojenej zlomeniny (Němejcová-Pavúková 1986, 150, obr. 10). Viaceré paralely k pochovávaniu 

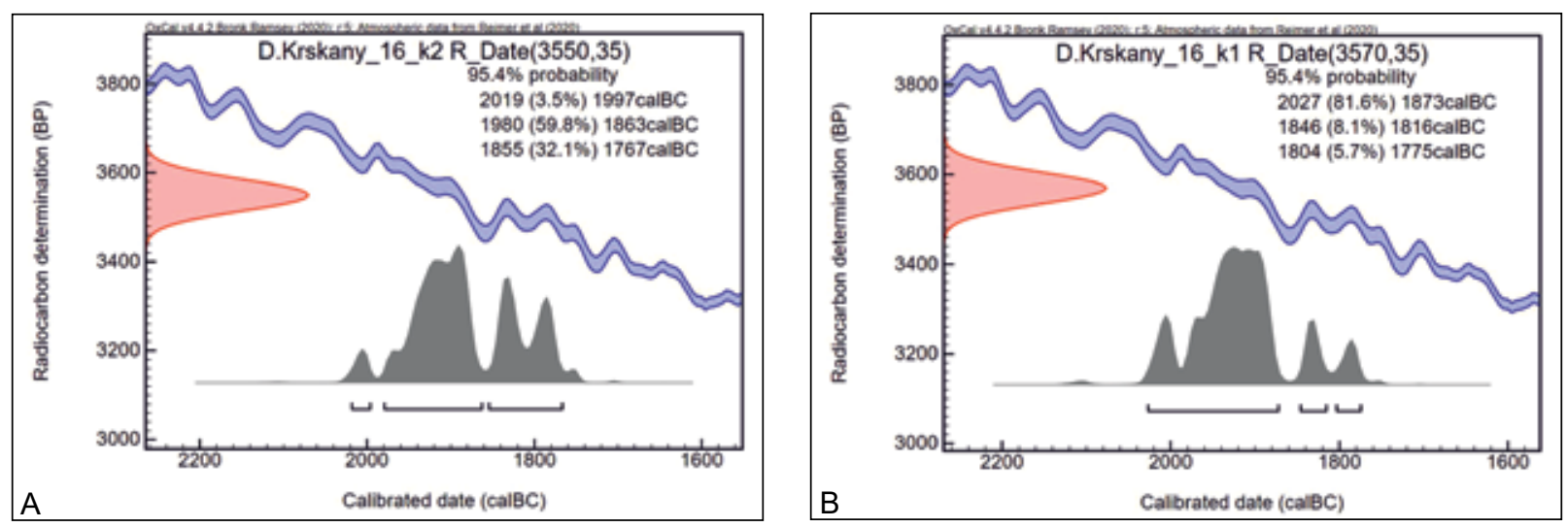

Obr. 10. Nitra-Dolné Krškany. Rádiouhlíkové datovanie skeletov č. 1 a 2 z objektu 16.

v tzv. žabej polohe predstavil aj P. Jelínek (2010), ktorý sa sústredoval skôr na prostredie únětickej kultúry. Pochovanie v „žabej“ polohe je doložené aj v hroboch nitrianskej kultúry. Niekedy však môže íst’ o pochovanie $\mathrm{v}$ polohe na chrbte s pokrčenými kolenami, ktoré v dôsledku rozpadu mäkkých tkanív poklesli k zemi do „žabej polohy“. To je pravdepodobne aj prípad hrobu so zrubovou konštrukciou č. 444 z Jelšoviec (Bátora 2000, 216, 217). V prípade skeletu č. 2 z Dolných Krškán však boli dolné končatiny mŕtveho uložené priamo do „žabej polohy“, ked'že ponad ne bol položený skelet dietata č. 1 .

Vyššie opísané uloženie tiel jedincov č. 1-5 v jame nemohlo byt̉ náhodné, ale muselo mat' v sebe hlbší zmysel. Svojou premyslenostou skôr odkazuje na jednoznačné kultové objekty ako napríklad nálezy z Nižnej Myšle či Spišského Štvrtku (Jakab/Olexal Vladár 1999).

Ako už bolo uvedené, podobné objekty nie sú na počiatku doby bronzovej úplne ojedinelým javom (Bátora 2018, 275-383). Blízka paralela zo začiatku 2. tisícročia pred n. l. je známa z nedalekej lokality Nitra-Selenec, kde sa na dne v pôdoryse kruhovej jamy č. 32 objavilo 5 skeletov. Daný objekt bol pôvodne priradený lengyelskej kultúre, avšak rádiouhlíkové datovanie potvrdilo jeho zaradenie do staršej doby bronzovej (Gabulová, v tlači; Gabulovál BistákoválJakab 2013, 63; Ruttkay a i. 2013). Išlo o pôvodne hlbšiu jamu, ked’že zemnými strojmi bola odstránená ornica, podorničie a $20-40 \mathrm{~cm}$ podložia. $\mathrm{V}$ jame bo uložený dospelý muž (E), dospelá žena (B), nedospelý muž (D) a dve deti (A a C). Zaujímavou je najmä skutočnost', že lebka dospelého muža aj so zvyškami prvých dvoch stavcov sa nachádzala pod jeho lavou rukou a čiastočne panvou, t. j. muž bol dekapitovaný, čo dokladajú aj stopy po zásekoch na stavcoch. ${ }^{3} \mathrm{Na}$ ženskej kostre (B) sa okrem iného zistila zriedkavá varieta na frontálnom výbežku lavej lícnej kosti a anomália lavej ruky, a to kongenitálna hypoplázia hlavice a proximálnej tretiny diafýzy ramennej kosti. Zjavne kratšie rameno ženy bolo zretelné už pri výskume. Na žene museli byt' na prvý pohlad viditelné znaky postihnutia. Na lebke nedospelého muža (D) sa zistili stopy po úderoch - pravdepodobne kamennou sekerou, na lebke a dlhých kostiach dietata $(\mathrm{C})$ sú doložené zlomeniny, iba na kostre dietata (A) sa nezistili žiadne stopy násilia (GabuloválBistákoválJakab 2013, 63, 64). Hypotetická interpretácia M. Gabulovej (v tlači), že „išlo o primárne nepietne pochovanie... Predchádzal mu pravdepodobne medziskupinový konflikt, ktorého výsledkom bolo zabitie skupinky tvorenej starším mužom, dospelou ženou, mladým chlapcom a dvomi malými deṫmi...", vyzerá byt vierohodná.

Na rozdiel od objektu č. 16 v Dolných Krškanoch, selenecký nález skôr evokuje rýchle vloženie mŕtvych do jamy, bez jednoznačného „scenára“, akoby rýchle zbavenie sa tiel.

Vel'kú podobnost' k analyzovanému objektu č. 16 má jama č. 60 z lokality Schleinbach v Dolnom Rakúsku (Pany-Kucera a i. 2020, obr. 8). Nad tromi detskými skeletmi v skrčenej polohe (dva na boku, jeden na bruchu) ležal skelet muža vo veku 30-35 rokov. Muž bol pochovaný vo vystretej polohe na chrbte, s mierne rozkročenými nohami a rukami $\mathrm{v}$ adoračnom geste a bol uložený $\mathrm{v}$ osi správne SVJZ. Rádiouhlíkové datovanie jedného zo skeletov (3500 \pm 30 pred n. 1.; Pany-Kucera a i. 2020, tabela 1) je takmer totožné s datovaním skeletov v Nitre-Dolných Krškanoch. Podobné je tiež pozorovanie, že „spodní" pochovaní jedinci v objekte pravdepodobne v čase pohrebu nemali na sebe odev, kedžze sa pri nich nenašli žiadne nálezy (ani súčasti odevu, ani

\footnotetext{
3 Aj ked’ sa uvádza, že sa stavce nezachovali (GabuloválBistákoválJakab 2013, 63).
} 
šperk). Kostra dospelého muža mala zahojenú ranu na lebke a viaceré poranenia boli identifikované aj na detských kostrách (Pany-Kucera a i. 2020, 28, 29).

Známe paralely jednoznačne naznačujú viaceré interpretačné možnosti. Často sa pohybujú v intenciách - náhoda, zámer, odpad (Müller 2006, 149). Viaceré znaky podporujú hypotézu, že niektoré hroby môžu byt̉ pozostatkami vojnových či epidemických situácií, alebo celkom prozaicky mohli byt' aj dôsledkom silného zamrznutia pôdy v zime (Langová/Danielisová 2015, 211). Ďalšie výskumy, napríklad z Brna-Tuřan, naznačujú, že v jamách mohli byt' pochovaní jedinci s nejakou odlišnostou - cudzí pôvod, podvýživa v detstve, tuberkulóza a podobne (LangoválDanielisová 2015, 212). Ničím výnimočným nie sú ani rôzne patologické defekty. Tu je potrebné upozornit na to, že podobné javy sa objavujú aj na „štandardných“ pohrebiskách. Tiež je nutné rozlišovat’ medzi tým, či boli jedinci uložení v zmysle dobových štandardov, alebo či boli do jamy iba vhodení, prípadne uložení v neobvyklej polohe.

V prípade objektu č. 16 z Dolných Krškán nemôže íst' o náhodu a určite nejde o formu "zbavenia sa tiel“. Mŕtvi boli do jamy dôsledne uložení a jama sa nezasypala, možno bola zakrytá dreveným poklopom alebo iným spôsobom. Taktiež málo pravdepodobne vyznieva teória o vojnovom konflikte. $\mathrm{V}$ takom prípade by nič nebránilo riadnemu pochovaniu tiel a v prípade nepriatelských obetí by pravdepodobne ich pochovaniu nebolo venované tol'ko pozornosti. $\mathrm{Z}$ vyššie uvedených úvah sa preto ako najpravdepodobnejší javí kultový zmysel objektu. Prečo potom neboli mútvi uložení v regulárnom viachrobe? Je možné, že mohlo íst’ o obrad v zime, kedy bolo komplikované vykopat jamu do zamrznutej pôdy. Ked'že bola využitá prázdna zásobná jama (tá mohla byt vykopaná aj pre tento kultový účel), je možné, že tu išlo o kultový obrad spojený s obetovaním a s naklonením si priazne božstiev zabezpečujúcich dobrú úrodu.

\section{Zázemie nálezu}

Objekt č. 16 z Dolných Krškán vhodne dopíňa poznatky o vývoji regiónu v staršom úseku staršej doby bronzovej (Točík 1963), kedy najmä západná terasa rieky Nitry patrí $\mathrm{k}$ najhustejšie osídleným územiam na západnom Slovensku (napríklad pohrebiská Branč: Vladár 1973; Mýtna Nová Ves: Bátora 1988, 88; Výčapy-Opatovce: Toč́́k 1979, 12; Nitra-
-Šindolka: Ruttkay/Ruttkayová 2005; Nitra-Mlynárce: Romsauer 1998). Približne 3 km severným smerom od analyzovanej lokality v Dolných Krškanoch sa preskúmalo pohrebisko nitrianskej kultúry v mestskej časti Nitra-Čermáň (Vladár/Bátora 2004) a 1,5 km severozápadne d’alšie pohrebisko v priestore závodu Bioveta (Rajček 1953; Hrmová 1954). Dokonca aj v bezprostrednom okolí v katastri Dolných Krškán je známych niekol'ko nálezísk z nitrianskej a únětickej kultúry (obr. 1). V roku 1984 bol približne 350 m severne od náleziska preskúmaný kostrový hrob skrčenca na pravom boku (orientácia SZ-JV) s medeným prsteňom listovitého tvaru (Császta 1985; Chropovský/Fusek 1983). Ešte bližšie, v areáli bývalého JRD vo vzdialenosti približne $100 \mathrm{~m}$ severne od nálezu, sa v roku 1960 zistila mohutná kultúrna vrstva s nálezmi keramiky nagyrévskej kultúry (Rajnič 1960). Približne z toho istého priestoru pochádzajú tri hroby skrčencov bez nálezov, preskúmané $\mathrm{v}$ roku 1958. Na laktovej kosti jedného z jedincov bola zachovaná zelená patina, naznačujúca prítomnost' medeného/bronzového náramku v hrobe (Hrmová 1958; Kolník 1958). Črepy zo zásypu objektu č. 16 dokazujú, že sa tu rozkladalo sídlisko nitrianskej kultúry, ktorého súčastou mohol byt’ aj samotný objekt. Je velmi pravdepodobné, že išlo o rozsiahlejší sídelný areál, ktorý tvorilo pohrebisko, sídlisko a jeho zázemie. Takýchto „buniek“ tu bolo niekol'ko. Potvrdzuje to aj skutočnost', že v rokoch 2019 a 2020 sa približne $800-850$ m južne od lokality preskúmalo pohrebisko nitrianskej kultúry na mieste výstavby priemyselného závodu Mühlbauer (Gabulová/Daňová/Nezvalová, v tlači).

\section{ZÁVER}

Vyššie uvedené informácie z lokality Nitra-Dolné Krškany dopĺnajú doteraz pomerne skromné poznatky o pochovávaní v mladom neolite $\mathrm{v}$ oblasti Nitry (fáza Lengyel I). Zároveň prinášajú presnejšie časové zaradenie, ako aj interpretáciu sídliskového objektu č. 16, v ktorom sa našlo 5 ludských skeletov datovaných do prvých dvoch storočí 2. tisícročia pred n. 1. Tie boli do jamy uložené pravdepodobne ako súčast' kultového rituálu. V oboch prípadoch (hrob č. 1 , objekt č. 16/skelet č. 1) išlo o prípady zavraždených jedincov prerazením lebky neznámym predmetom. Nové rádiouhlíkové dáta sú taktiež prínosom pre lepšie poznanie daných období na západnom Slovensku. 


\section{LITERATÚRA}

Bartík 2018 - J. Bartík: Pohrebisko zo staršej doby bronzovej v Šoporni. Zborník SNM 112. Archeológia 28, 2018, 21-47.

Bátora 1988 - J. Bátora: Najnovšie poznatky o pohrebnom ríte l'udu nitrianskej skupiny. In: M. Dočkalová (ed.): Antropofagie a pohřební ritus doby bronzové. Brno 1988, 83-90.

Bátora 2000 - J. Bátora: Das Gräberfeld von Jelšovce/Slowakei. Ein Beitrag zur Frühbronzezeit im nordwestlichen Karpatenbecken. Teil 1-2. PAS 16. Kiel 2000.

Bátora 2006 - J. Bátora: Štúdie ku komunikácii medzi strednou a východnou Európou v dobe bronzovej. Bratislava 2006.

Bátora 2018 - J. Bátora: Slovensko v staršej dobe bronzovej. Nitra 2018.

Benkovsky-Pivovarová 2011 - Z. Benkovsky-Pivovarová: Datovanie konca nitrianskej kultúry vo svetle rádiokarbónových dát z Jelšoviec. Pravěk NǨ 11, 2011, 221-231.

Benkovsky-Pivovarová/Chropovský 2015 - Z. Benkovsky-Pivovarová/B. Chropovský 2015: Grabfunde der frühen und der beginnenden mittleren Bronzezeit in der Westslowakei. Teil 2. Archaeologica Slovaca Monographiae. Studia 22. Nitra 2015.

Bernard 2005 - Ch. Bernard: Die Nitragruppe in der Südwestslowakei. Eine archäologische und paläometallurgische Analyse ausgewählter Gräberfelder. Saarbrücken 2005.

Bronk Ramsey a i. 2020 - T. J. Heaton/M. Blaauw/P. G. Blackwell/Ch. Bronk Ramsey/P. J. Reimer/M. Scott: The IntCal20 Approach to Radiocarbon Calibration Curve Construction: A New Methodology Using Bayesian Splines and Errors-in-Variables. Radiocarbon 62 (4), 2020, 821-863.

Budinský-Krička 1947 - V. Budinský-Krička: Slovensko v mladšej dobe kamennej. In: B. Varsík (ed.): Slovenské dejiny I. Slovensko v praveku. Bratislava 1947, 55-67.

Császta 1985 - J. Császta: Nitra, Dolné Krškany. Nálezová správa AÚ SAV v Nitre č. 11140/85. Nitra 1985.

Ecsedy 1979 - I. Ecsedy: The people of the Pit-grave kurgan in Eastern Hungary. Fontes Archaeologici Hungariae 17. Budapest 1979.

Farkaš 1999 -Z. Farkaš: K otázke žiarového pohrebného rítu ludu s lengyelskou kultúrou v období mladého neolitu. Sborník prací Filozofické fakulty Brněnské univerzity M4, 1999, 119-127.

Gabulová, v tlači - M. Gabulová: Sídlisko ludanickej skupiny $v$ Nitre-Selenci. Nitra, v tlači.

Gabulová/Bistáková/Jakab 2013 - M. Gabulová/A. Bistáková/ J. Jakab: L’udské skelety na sídlisku ludanickej skupiny v Nitre-Selenci. In: I. Cheben/M. Soják (ed.): Otázky neolitu a eneolitu našich krajín - 2010. Zborník referátov z 29. pracovného stretnutia bádatelov pre výskum neolitu a eneolitu Čiech, Moravy a Slovenska, Vršatské Podhradie, 27.-30. 9. 2010. Archaeologica Slovaca Monographiae. Communicationes 15. Nitra 2013, 57-73.

Gabulová/Daňová/Nezvalová, v tlači-M. Gabulová/K. Daňová/L. Nezvalová: Výskum sídliska a pohrebiska v Nitre, čast' Dolné Krškany. AVANS 2019, v tlači.

Gabulová/Kuzma 2015 -M. Gabulová/I. Kuzma: Pochovávanie na sídlisku ludanickej skupiny v Nitre-Mlynárciach. Slovenská archeológia 53, 2015, 179-208.

Gerloff 1993 - S. Gerloff: Zu Fragen mittelmeerländischer Kontakte und absoluter Chronologie der Frühbronzezeit in Mittel- und Westeuropa. Prähistorische Zeitschrift 63, 1993, 58-102.
Görsdorf 2000 - J. Görsdorf: Interpretation der Datierungsergebnisse von Menschenknochen aus dem Gräberfeld Jelšovce. In: J. Bátora: Das Gräberfeld von Jelšovcel Slowakei. Ein Beitrag zur Frühbronzezeit im nordwestlichen Karpatenbecken. Teil 2. PAS 16. Kiel 2000, 565-570.

Hrmová 1954 - M. Hrmová: Nitra, Dolné Krškany, Serologický ústav. Nálezová správa AÚ SAV v Nitre č. 77/54. Nitra 1954.

Hrmová 1958 - M. Hrmová: Nitra, Dolné Krškany, zeleninová záhrada JRD. Nálezová správa AÚ SAV v Nitre č. 25/58. Nitra 1958.

Hukelová a i. 2020 - Z. Hukelová/Z. Bielichová/M. Krošláková/K. Daňová/M. Cheben: Nosila rúško? Osteoarcheologický rozbor hrobu zo sídliska zo staršej doby bronzovej v Zbehoch. In: A. Kozubová/E. Makarová/ M. Neumann (ed.): Ultra velum temporis. Venované Jozefovi Bátorovi $k$ 70. narodeninám. Slovenská archeológia - Supplementum 1. Nitra 2020, 225-236.

Cheben 2012 - I. Cheben: Siedlung und Gräberfeld der Aunjetitzer Kultur in Pata. In: R. Kujovský/V. Mitáš (ed.): Václav Furmánek a doba bronzová. Zborník k sedemdesiatym narodeninám. Archaeologica Slovaca Monographiae. Communicationes 13. Nitra 2012, 119-127.

Chropovský/Fusek 1985 - B. Chropovský/G. Fusek: Výskumy v Nitre. AVANS 1984, 1985, 105, 106.

Jakab 2005 - J. Jakab: Nitra, Dolné Krškany - antropologický posudok. Nálezová správa AÚ SAV v Nitre č. 15678/2005. Nitra 2005.

Jakab/Olexa/Vladár 1999 - J. Jakab/L. Olexa/J. Vladár: Ein Kultobjekt der Otomani-Kultur in Nižná Myšla. Slovenská archeológia 47, 1999, 91-127.

Jelínek 2010 - P. Jelínek: Príspevok k interpretácii tzv. masových hrobov z prostredia únětickej kultúry. In: R. Tichý (ed.): Hroby, pohřby a lidské pozůstatky na pravěkých a stř́edověkých sídlištích. Živá archeologie. (Re)konstrukce a experiment $\mathrm{v}$ acheologii. Supplementum 3. Hradec Králové 2010, 93-100.

Kolník 1958 - T. Kolník: Nitra, Dolné Krškany, stavba kravínov JRD. Nálezová správa AÚ SAV v Nitre č. 63/58. Nitra 1958.

Kuča a i. 2012 - M. Kuča/M. Nývltová Fišáková/P. Škrdla/ M. Vokáč: Lokalita staršího stupně kultury s moravskou malovanou keramikou v Březníku na Českomoravské vrchovině. Sborník prací Filozofické fakulty Brněnské univerzity M17, 2012, 95-120.

Kujovský/Žebrák 1984 - R. Kujovský/P. Žebrák: Nové nálezy z Lefantoviec. AVANS 1983, 1984, 130, 131.

Kuzma/Jakab/Kopčeková 2010 - I. Kuzma/J. Jakab/M. Kopčeková: Pohreby na sídlisku ludanickej skupiny v Nitre-Mlynárciach. In: R. Tichý (ed.): Hroby, pohřby a lidské pozůstatky na pravěkých a středověkých sídlištích. Živá archeologie. (Re)konstrukce a experiment v acheologii. Supplementum 3. Hradec Králové 2010, 65-76.

Langová/Danielisová 2015 - M. Langová/A. Danielisová: Sídlištní areál starší doby bronzové v Brandýse nad Labem. Objekty s lidkými a kosterními pozůstatky. In: J. Bátora/ P. Tóth (ed.): Ked'bronz vystriedal med'. Zborník príspevkov z XXIII. medzinárodného sympózia „Staršia doba bronzová v Čechách, na Morave a na Slovensku“. Levice 8.-11. októbra 2013. Bratislava - Nitra 2015, 201-216.

Lenneis Hrsg. 2017 - E. Lenneis: Erste Bauerndörfer - älteste Kultbauten. Die frühe und mittlere Jungsteinzeit in Niederösterreich. Archäologie Niederösterreichs 1. Wien 2017. 
Lichardus/Vladár 1964 - J. Lichardus/J. Vladár: Zu Problemen der Ludanice Gruppe in der Slowakei. Slovenská archeológia 12, 1964, 69-162.

Lichardus/Vladár 1970 - J. Lichardus/J. Vladár: Neskorolengyelské sídliskové a hrobové nálezy z Nitry. Slovenská archeológia 18, 1970, 373-412.

Mateiciucová 2017 - I. Mateiciucová: Formenkunde der geschlagenen Steinindustrie. In: E. Lenneis (Hrsg.): Erste Bauerndörfer - älteste Kultbauten. Die frühe und mittlere Jungsteinzeit in Niederösterreich. Archäologie Niederösterreichs 1. Wien 2017, 352-355.

Müller 2006 - U. Müller: Zufall - Absicht - Abfall? Siedlungsbestattungen im bronzezeitlichen Esperstedt. In: H. Meller (Hrsg.): Archäologie auf der Überholspur. Ausgrabungen an der A 38. Archäologie in Sachsen-Anhalt. Sonderband 5. Halle (Saale) 2006, 148-159.

Němejcová-Pavúková 1986 - V. Němejcová-Pavúková: Vorbericht über die Ergebnisse der systematischen Grabung in Svodín in den Jahren 1971-1983. Slovenská archeológia 34, 1986, 133-176.

Neubauer 2017 - W. Neubauer: Kreisgrabenanlagen (4850/4750 - 4650/4500 BC). In: E. Lenneis (Hrsg.): Erste Bauerndörfer - älteste Kultbauten. Die frühe und mittlere Jungsteinzeit in Niederösterreich. Archäologie Niederösterreichs 1. Wien 2017, 276-313.

Novotný 1958 - B. Novotný: Slovensko v mladšej dobe kamennej. Bratislava 1958.

Novotný 1962 - B. Novotný: Lužianska skupina a počiatky malovanej keramiky na Slovensku. Bratislava 1962.

Ondráček 1963 - J. Ondráček: Nálezy mierzanovicko-nitranského typu na Moravě. Archeologické rozhledy 15, 1963, 405-415.

Pany-Kucera a i. 2020 - D. Pany-Kucera/M. Spannagl-Steiner/L. Waltenberger/W. Parson/Ch. Strobl/ B. Rendl/L. Janker/F. Kanz/K. Rebay-Salisbury: Social Relations, Deprivation and Violence at Schleinbach, Lower Austria. Insights from an Interdisciplinary Analysis of the Early Bronze Age Human Remains. Archaeologia Austriaca 104, 2020, 13-52.

Pavúk 1984 - J. Pavúk: Štvrtý rok výskumu sídliska lengyelskej kultúry v Žlkovciach. AVANS 1983, 1984, 175-177.

Pavúk 1993 - J. Pavúk: Osídlenie Nitry v mladšej a neskorej dobe kamennej. In: K. Pieta (ed.): Nitra. Príspevky knajstarším dejinám mesta. Nitra 1993, 15-23.

Pavúk/Bátora 1995 - J. Pavúk/J. Bátora: Siedlung und Gräber der Ludanice-Gruppe in Jelšovce. Nitra 1995.

Pažinová/Bistáková 2013 - N. Pažinová/A. Bistáková: Menschliche Skelettreste aus bronzezeitlichen Siedlungen in der Slowakei. In: N. Müller-Scheeßel (Hrsg.): ,Irreguläre' Bestattungen in der Urgeschichte: Norm, Ritual, Strafe ...? Akten der Internationalen Tagung in Frankfurt a. M. vom 3. bis 5. Februar 2012. Kolloquien zur Vor- und Frühgeschichte 19. Bonn 2013, 151-165.

Peška/Tajer 2015 - J. Peška/A. Pajer: Problematika epišňůrových sídlišt na Moravě - stav poznání. In: J. Bátora/ P. Tóth (ed.): Ked'bronz vystriedal med'. Zborník príspevkov z XXIII. medzinárodného sympózia „Staršia doba bronzová v Čechách, na Morave a na Slovensku“. Levice 8.-11. októbra 2013. Bratislava - Nitra 2015, 77-104.

Porubský 1955 - J. Porubský: Hroby z mladšej doby kamennej vo Výčapoch-Opatovciach, okres Nitra. Archeologické rozhledy 7, 1955, 437-443.

Raczky/Anders 2010 - P. Raczky/A. Anders: The times they are a-changin'. Revisiting the chronological framework of the Late Neolithic settlement complex at Polgár-Csőszhalom. In: J. Šuteková/P. Pavúk/P. Kalábková/ B. Kovár (eds.): PANTA RHEI. Studies on the Chronology and Cultural Development of South-Eastern and Central Europe in Earlier Prehistory. Presented to Juraj Pavúk on Occasion of his $75^{\text {th }}$ Birthday. Bratislava 2010, 357-378.

Rajček 1953 - J. Rajček: Nitra, Dolné Krškany. Nálezová správa AÚ SAV v Nitre č. 403/60. Nitra 1953.

Rajnič 1960 - A. Rajnič: Nitra, Dolné Krškany, hospodárske budovy JRD. Nálezová správa AÚ SAV v Nitre č. 183/60. Nitra 1960.

Reimer a i. 2013 - P. J. Reimer/E. Bard/A. Bayliss/J. W. Beck/ P. G. Blackwell/C. Bronk Ramsey/C. E. Buck/H. Cheng/ R. L. Edwards/M. Friedrich/P. M. Grootes/T. P. Guilderson/H. Haflidason/I. Hajdas/C. Hatté/T. J. Heaton/ D. L. Hoffman/A. G. Hogg/K. A. Hughen/K. F. Kaiser/B. Kromer/S. W. Manning/M. Niu/R. W. Reimer/ D. A. Richards/E. M. Scott/J. R. Southon/R. A. Staff/ C. S. M. Turney/J. van der Plicht: IntCal13 and Marine13 radiocarbon age calibration curves $0-50,000$ years cal BP. Radiocarbon 55 (4), 2013, 1869-1887.

Romsauer 1998 - P. Romsauer: Doba bronzová. In: G. Fusek/M. R. Zemene/P. Bednár (ed.): Dejiny Nitry od najstarších čias po súčasnost’. Nitra 1998, 39-50.

Ruttkay 2004 - M. Ruttkay: Záchranný výskum v Nitre-Dolných Krškanoch. AVANS 2003, 2004, 153-155.

Ruttkay 2018 - M. Ruttkay: Hrobové nálezy z Nitry Svätoplukovho námestia. In: J. Bátora/R. Kujovský/ M. Ruttkay/J. Vladár (ed.): Anton Točík-legenda slovenskej archeológie. Archaeologica Slovaca Monographiae. Communicationes 20. Nitra 2018, 145-159.

Ruttkay a i. 2013 - M. Ruttkay/H. Baliová/P. Bednár/ M. Bielich/A. Bistáková/J. Ďuriš/M. Gabulová/J. Haruštiak/M. Jakubčinová/R. Malček/V. Mitáš/M. Vojteček: Záchranné archeologické výskumy na trase rýchlostnej cesty R1 v úseku Nitra-Selenec - Beladice. AVANS 2009, 2013, 209-229.

Ruttkay/Ruttkayová 2005 - M. Ruttkay/J. Ruttkayová: Záchranný archeologický výskum v Nitre-Śindolke. AVANS 2004, 2005, 174.

Ruttkayová 1998 - J. Ruttkayová: Doba kamenná. In: G. Fusek/M. R. Zemene/P. Bednár (ed.): Dejiny Nitry od najstarších čias po súčasnost’. Nitra 1998, 23-38.

Stadler/Ruttkay 2007 - P. Stadler/E. Ruttkay: Absolute chronology of the Moravian-Eastern-Austrian Group (MOG) of the Painted Pottery (Lengyel-Culture) based on new radiocarbon dates from Austria. In: P. Raczky/ J. K. Kozlowski (eds.): The Lengyel, Polgár and related cultures in the Middle/Late Neolithic in Central Europe. Kraków 2007, 117-146.

Točík 1963 - A. Točík: Die Nitra Gruppe. Archeologické rozhledy 15, 1963, 716-774.

Točík 1979 - A. Točík: Výčapy-Opatovce a d'alšie pohrebiská zo staršej doby bronzovej na juhozápadnom Slovensku. Nitra 1979.

Točík/Vladár 1971 - A. Točík/J. Vladár: Prehlad bádania v problematike vývoja Slovenska v dobe bronzovej. Slovenská archeológia 19, 1971, 365-422.

Vladár 1973 - J. Vladár: Pohrebiská zo staršej doby bronzovej $v$ Branči. Nitra 1973.

Vladár/Bátora 2004 - J. Vladár/J. Bátora: Pohrebiská nitrianskej kultury v Nitre. In: E. Kazdová/Z. Měřínský/ K. Šabatová (ed.): K poctě Vladimíru Podborskému. Prátelé $a$ žáci k sedmdesátým narozeninám. Brno 2004, 245-257. 
Rukopis prijatý 28. 8. 2020

Translated by Magdalena Adamus doc. PhDr. Matej Ruttkay, CSc.

Archeologický ústav SAV

Akademická 2

SK - 94921 Nitra

matej.ruttkay@savba.sk

\title{
A Neolithic Grave (?) and a Feature with Cult Function from the Early Bronze Age in Nitra-Dolné Krškany
}

\author{
Matej Ruttkay
}

SUMMARY

The study aims to discuss the Late Neolithic grave (settlement feature?) and the storage pit containing remains of five humans from the Early Bronze Age investigated during excavation in Nitra-Dolné Krškany in 2003. In both cases, findings are supported by new radiocarbon data. The author dedicates the study to prof. PhDr. Jozef Bátora, DrSc. who significantly contributed to the research and popularisation of many magnificent prehistoric monuments in Slovakia, particularly those from the Bronze Age.

\section{Grave no. 1.}

Grave no. 1 (Fig. 2: 1) contained a female skeleton, maturus II/50-60 years old, buried in a heavily crouched position on her right side (anthropological description based on Jakab 2005). The contours of the pit were unclear and, thus, it was impossible to determine whether it was a regular grave or a settlement pit. The body was oriented SWWW-NEEE, with the head directed to the West, face to the South-East. Traces of healed injuries were visible on the left side of the parietal bone. In the right temporal bone, there was an artificial opening made around the time of death. The grave contained two fragments of vessels, a piece of a bone tool and an obsidian microlithic tool. Calibrated radiocarbon dates (4790-4580 BC; $95.4 \%$ ) allow to attribute the grave to the beginnings of Lengyel culture, specifically to its phase I (Fig. 3; 4). It would certainly be interesting to compare the grave with the Protolengyel phase which is sometimes dated to the period after 4800 BC (Stadler/Ruttkay 2007, 132). In the Nitra region, finds from graves attributed to the phase I of Lengyel culture are exceptional, even though such finds from other phases of Lengyel culture are relatively common in this region (Pavúk 1993; Pavúk/Bátora 1995, 121-124; Pažinová/Bistáková 2013; Ruttkayová 1998). Numerous settlement finds are also known from the direct vicinity of the site discussed in the present study.

Feature no. 16

Five skeletons were found at the bottom of the conical storage pit - four skeletons were put one above another and the fifth one was placed in the western part of the pit on its abdomen (Fig. 5-8). Only skeleton no. 1 was accompanied by finds - two copper wire rings and two ornaments made of boar tusks. Skeleton no. 1 - a child (infans III/6-7 years old) - had an opening on the right side of the skull, most likely an injury inflicted around the time of death with a pointed object. Skeleton no. 2 - an adult man (maturus II/50-60 years old) - placed in a so-called frog position on his back. Skeleton no. 3 - a child (infans III/10-11 years old). Skeleton no. 4 - an adult man (adultus I/20-30 years old). Skeleton no. 5 - a child (infans III/7-9 years old). Radiocarbon dating of two of these skeletons $(1,2)$ made at the laboratory in Poznan provides more precise data. Skeleton no. 1 is dated back to $3570 \pm 35 \mathrm{BP}$ and skeleton no. 2 is dated back to $3550 \pm 35$ BP (Fig. 10). This means that the absolute dating of skeleton no. 1 falls most likely to the range between 2027 and 1775 BC (95.4\%) and the skeleton of the older individual between 2019 and 1767 BC (95.4\%). The findings correlate well with neighbouring burial grounds in Branč a Jelšovce (Fig. 9; Gerloff 1993; Görsdorf 2000, 567). Almost identical dates are known from the Nitra-Selenec site (2020-1774 BC; Gabulová, v tlači). A skeleton from a settlement located in the Nitra Valley in Zbehy was dated as slightly older (2030-1826 BC; Hukelová a i. 2020). A burial ground attributed to Nitra culture in Nitra at the Svätopluk Square is dated as significantly older (2286-2036 BC; Ruttkay 2018). As can be seen from the graph (Fig. 9) showing basic currently known calibrated dates from the Nitra region and selected neighbouring regions, the dates from Dolné Krškany indicate that, most likely, the deceased were deposited in the grave during the classic or the youngest Nitra-Únětice phase of Nitra culture (according to Točík/Vladár 1971). At the same time, the findings point to certain discrepancies between the absolute dates and the commonly accepted relative chronology and open questions about possible parallel existence of Nitra culture and Únětice culture. Recently, several authors warned of this possibility (Benkovsky-Pivovarová 2011; Peška/Tajer 2015).

It seems highly probable that individual no. 4 was deposited in the grave as first (Fig. 6: 1). If skeletons nos. 3 and 5 had already been there, it would have 
been technically unfeasible to place the individual no. 4 at the bottom of the pit. Furthermore, the head of the skeleton no. 3 was leant on the no. 4's head. It means that individuals nos. 3 and 5 were buried in the grave as second and third, back to back (Fig. 6: 2). This created a clear bipolar situation. Judging by the position of the bodies - one put on the right side and the other put on the left side - the deceased could have been a boy and a girl. Then the individual no. 2 - as a central point of the feature - was deposited in the centre of the pit, in so-called frog position with his hands in an artificial adoring gesture (Fig. 6: 3). Finally, a killed child (skeleton no. 1) - the only individual accompanied by findings - was placed on the individual no. 2 .

In the next part, the author presents some parallels to the feature no. 16 (Bátora 2018, 275-383; Gabulová, v tlači; Gabulová/Bistáková/Jakab 2013, 63; Hukelová a i. 2020; Cheben 2012, 123; Pany-Kucera a i. 2020, fig. 8; Pavúk 1984, 176). Known parallels point to several possible interpretations concerning intention of deposition - ranging from randomness through intention to disposal (Müller 2006, 149). Numerous traces support the hypothesis that some of the graves could have been related to wars or epidemics, foreign elements or, simply, could have been consequences of heavily frozen soil in winter (Langová/Danielisová 2015, 211, 212). Pathological defects are also nothing unique. However, we should warn that similar phenomena as those observed here are also known from 'standard' burial grounds. It is necessary, thus, to distinguish between individuals deposited in accordance with contemporary standards and those discarded or placed in a grave in an unusual position.

Fig. 1. Nitra-Dolné Krškany. Location of the site (e) with marked archaeological sites in the direct vicinity mentioned in the text. Lengyel culture: a - settlement; b - burial ground. Early Bronze Age: $\mathrm{c}$ - settlement; d - burial ground. 1 - TONEX; 2 - JRD; 3 - Plastika; 4 - terrace; 5 - Mühlbauer.

Fig. 2. Nitra-Dolné Krškany, grave no. 1 (drawing of finds by E. Bakytová, photo and plan drawing by M. Ruttkay).

Fig. 3. Nitra-Dolné Krškany. Radiocarbon dating of grave no. 1.

Fig. 4. Selected radiocarbon data of Lengyel culture in Western Slovakia (after Gabulová, v tlači; Němejcová-Pavúková 1986, 155; Pavúk/Bátora 1995, 110, 111).

Fig. 5. Nitra-Dolné Krškany, feature no. 16. 1, 5 - skeleton $1 ; 2$ - skeleton 2; 3, 6 - skeleton 4; 4 - skeleton 3; 7 - skeletons 2, 3, 4 (photo by J. Jakab, M. Ruttkay).
In the case of feature no. 16 from Nitra-Dolné Krškany, the hypothesis that the bodies were placed randomly in the grave or discarded could be rejected. The deceased were carefully placed in the grave and the pit was not filled up. Possibly it was covered with wood or some other material. It seems equally improbable that the grave was dug during a war. In such a case, nothing would prevent the bodies from being buried properly and if the deceased were enemies, they would have not been buried with such a care. All these indicate the cult interpretation of the feature as the most probable one. Possibly, it was a cult burial accompanied by offerings to gain favours of deities (e. g. part of harvest).

The investigated feature matches to the extremely dense network of Nitra culture burial sites around Nitra dated to the time when mainly the western bank of the Nitra River belonged to the most densely populated areas in today Western Slovakia (Bátora 1988, 88; Császta 1985; Gabulovál Daňová/Nezvalová, v tlači; Hrmová 1954; 1958; Chropovskýl Fusek 1985; Kolník 1958; 1983; Rajček 1953; Romsauer 1998; Ruttkay/Ruttkayová 2005; Točík 1963; Točík 1979, 12; Vladár 1973; Vladár/Bátora 2004).

The grave discussed in this paper extends the relatively scarce knowledge about burial rituals during Neolithic in the Nitra region (Lengyel culture, phase I). Furthermore, the analysis allows for more precise dating and interpretation of the settlement feature no. 16. In both cases (grave no. 1 , feature no. 16/skeleton no. 1) the deceased died due to head injuries inflicted by an unknown weapon. Finally, new radiocarbon dates contribute to better knowledge about prehistoric society in today Western Slovakia.

Fig. 6. Nitra-Dolné Krškany. Skeletons at the pit bottom and plans showing the bodies deposition sequence in the feature no. 16, starting from the skeleton no. 1 to no. 4 (author M. Ruttkay, redrawing by B. Balžan).

Fig. 7. Nitra-Dolné Krškany. Findings from the feature no. 16. $1-4$ - finds found by the skeleton no. $1 ; 5$ - pottery sherd from the feature backfill (drawing and photo by E. Bakytová).

Fig. 8. Nitra-Dolné Krškany. Details of the injuries on the skull of skeleton no. 1 from the feature no. 16 (photo by J. Jakab).

Fig. 9. Nitra-Dolné Krškany, feature no. 16. Selected radiocarbon data of human skeletons and animal bones from the older section of the Early Bronze Age. Full circle - site TONEX; ring - Nitra area.

Fig. 10. Nitra-Dolné Krškany. Radiocarbon dating of skeletons no. 1 and 2 from the feature no. 16 . 